\title{
LA MUJER COMO TENTACIÓN MALIGNA
}

\section{WOMAN AS EVIL TEMPTATION}

EMAKUMEA MALTZURKERIAREN TENTAZIOA

RESUMEN: El imaginario de los castigos y tormentos a los pecadores es probablemente una de las creaciones más originales y persuasivas de la iconografía medieval. Tan seductoras como repulsivas, la capacidad de comunicación de estas imágenes es infalible, ya que se convierten en agentes activos que interactúan directamente con el público al que van dirigidas. Entre todas ellas hay una que destaca por su rotundidad y por su impacto visual y que la historiografía francesa ha d e n o m in a d o femme-aux-serpents, iconografía predilecta para ilustrar el castigo a la lujuria.

PALABRAS CLAVE: Tierra-Madre; lujuria; mentalidad monástica; mujer, iconografía; textos escritos.
ABSTRACT: The imaginary of the punishments and torments to the sinners is probably one of the most original and persuasive creation of medieval iconography. The capacity of communication of these fascinating and disgusting images is inevitable as they turn into active agents which interact directly with the public whom they are pointed. Among all of them, there is one that stands out for her firmness and for her visual impact. That is the one that French historiography has named as femmeaux-serpents, the favorite iconography to illustrate the punishment to the lust.

KEYWORDS: Earth-Mother; Lust; Monastic mentality; Woman Iconography; Written texts.
LABURPENA: Pekatarien zigorren eta oinazen irudikapena Erdi Aroko ikonografiaren sorkuntza guztiz limurtzaile eta originala dugu. Irudikapen liluragarri eta higuingarri hauen mezu zabaltze gaitasuna hutsezina da, zuzenduriko garaiko herriarekiko eragile erangikorrak dira. Guztien artean, bere tinkotasunarengatik eta eragiten duen ikus-zirrararengatik femme-auxserpents frantziar historiografiak deituriko ikonografia nabarmentzen da, lizunkeriaren zigorra irudikatzeko aldaera ikonografiko onargarriena.

GAKO-HITZAK: Ama-Lurra; Lizunkeria Fraide-mentalitatea; Emakumea; Ikonografia; Testu idatziak.
MARTÍNEZ DE LAGOS, Miren Eukene

Universidad del País Vasco (UPV/EHU)

\begin{abstract}
Facultad de Letras
Paseo de la Universidad, 5

01006 Vitoria (Álava)

mariaeugenia.martinez@ehu.eus
\end{abstract}

ORCID ID: 0000-0003-4978-4048

Este artículo ha sido realizado en el marco del proyecto de investigación El Sentimiento del Amor en el Arte de la Baja Edad Media, n.o ref. $\mathrm{EHU} / 1430,14$ (B) subvencionado por el Vicerrectorado de Investigación de la UPV/EHU.

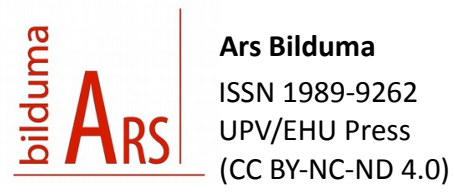

https://doi.org/10.1387/ars-bilduma.16524 BIBLID [(2017), 7; 13-52]

Recep.: 22/06/2016 Acept.: 15/10/2016 
Abordar el análisis del motivo iconográfico de la femme aux serpents implica prestar una especial atención a estudios anteriores que ya pusieron de manifiesto que la figura de referencia era la Tierra-Madre del Arte Clásico. Por ello y considerando lo analizado hasta hoy día, esta aportación tiene como objetivo fundamental profundizar en la transmutación iconográfica y semántica de esta imagen desde la representación pagana hasta la medieval, prestando especial atención a una serie de referencias iconográficas y textos escritos escasamente considerados hasta la fecha.

En el Clm 14399 conservado en la Bayerische Staatsbibliothek de München, códice del siglo XII que contiene el Hexameron de San Ambrosio, la miniatura del fol. $40^{1}$ llama poderosamente la atención. En dicha miniatura la imagen de la Tierra, representada para ilustrar el pasaje relativo al tercer día de la Creación narrado en el Génesis, sorprende por sus evidentes relaciones con algunas de las innumerables femme aux serpents que para ese momento se habían difundido por todo el Occidente europeo. Aunque inspirada en algunas de las imágenes antiguas y medievales de la Tierra-Madre, dicha representación parece haber realizado el camino inverso al trazado por la historiografía de las últimas décadas $^{2}$ (Fig. 1).

Fue Émile Mâle el primero en señalar que la imagen de la femme aux serpents derivaba de las representaciones de la Tierra-Madre en la iconografía antigua y Jean Adhémar quien abordó la metamorfosis y difusión de este motivo ${ }^{3}$. En 1975 Jacqueline Leclercq-Kadaner publicó un

1 Esta miniatura ya fue destacada en una aportación anterior. MARTíNEZ DE LAGOS, E.: "Discursos visuales y mentalidad religiosa. La femme-aux-serpents y el uso de imágenes antitéticas en la escultura románica", Brocar, no 38, 2014, p. 64.

2 No se trata de un caso aislado, ya que también podemos observar el mismo paralelismo en las representaciones de la Tierra que figuran en un capitel de la Portada de Urcel o en otro de St. María zur Höhe en Soest.

3 MÂLE, E.: L'Art religieux du XII siécle en France. Etude sur les origines de l'iconographie artículo, ya clásico, profundizando en su transmutación iconográfica y semántica ${ }^{4}$. Numerosos estudios posteriores han seguido su estela aportando nuevos datos para la comprensión de un motivo iconográfico especialmente singular, no sólo por su extraordinaria difusión, sino también porque la femme aux serpents resulta ser tremendamente ambigua, tan indiscutiblemente atractiva para su análisis como repulsivas son sus representaciones. Son razones que me han llevado, una vez más, a profundizar en su análisis prestando especial atención a algunas referencias iconográficas y fuentes escritas muy significativas que hasta el momento no han sido objeto de atención en relación a este tema.

Ahora bien, el análisis no se puede limitar únicamente a una cuestión de filiación iconográfica, ya que en la construcción de esta imagen confluyen diversos aspectos. Ocupa un lugar preponderante la consideración de la mujer, claramente negativa según la visión misógina del discurso patrístico, un discurso que va a determinar la construcción de una mentalidad básicamente monástica que asocia la naturaleza femenina con la tentación, el sexo y el pecado. Dicha mentalidad va a influir de manera decisiva en amplios sectores del estamento religioso, por no decir en casi todos, y cristaliza a lo largo del siglo XI para crear una imagen impactante. Utilizaran para ello algunos elementos de la figura antigua, la que legitimaba su uso como iconografía de referencia, pero la reinterpretarán creando una nueva en base a las ideas religiosas imperantes.

du Moyen Âge. París, A. Colin, 1922, p. 375. ADHÉMAR, J.: Influences antiques dans I 'art du Moyen Age français. London, The Warburg Institute, 1939, pp. 197-200.

4 LECLERCQ-KADANER, J.: "De la Terre-Mére á la Luxure. A propos de "La migration des symboles", Cahiers de Civilisation Médiévale, XVIII, 1975, pp. 37-43. La autora señala a comienzo de su estudio que el artículo se centra en las alteraciones formales y las transferencias semánticas de una iconografía que es claro ejemplo de la transmutación de un símbolo en otro símbolo que difiere claramente del originario, pero con el que mantiene vínculos sutiles y esenciales. 


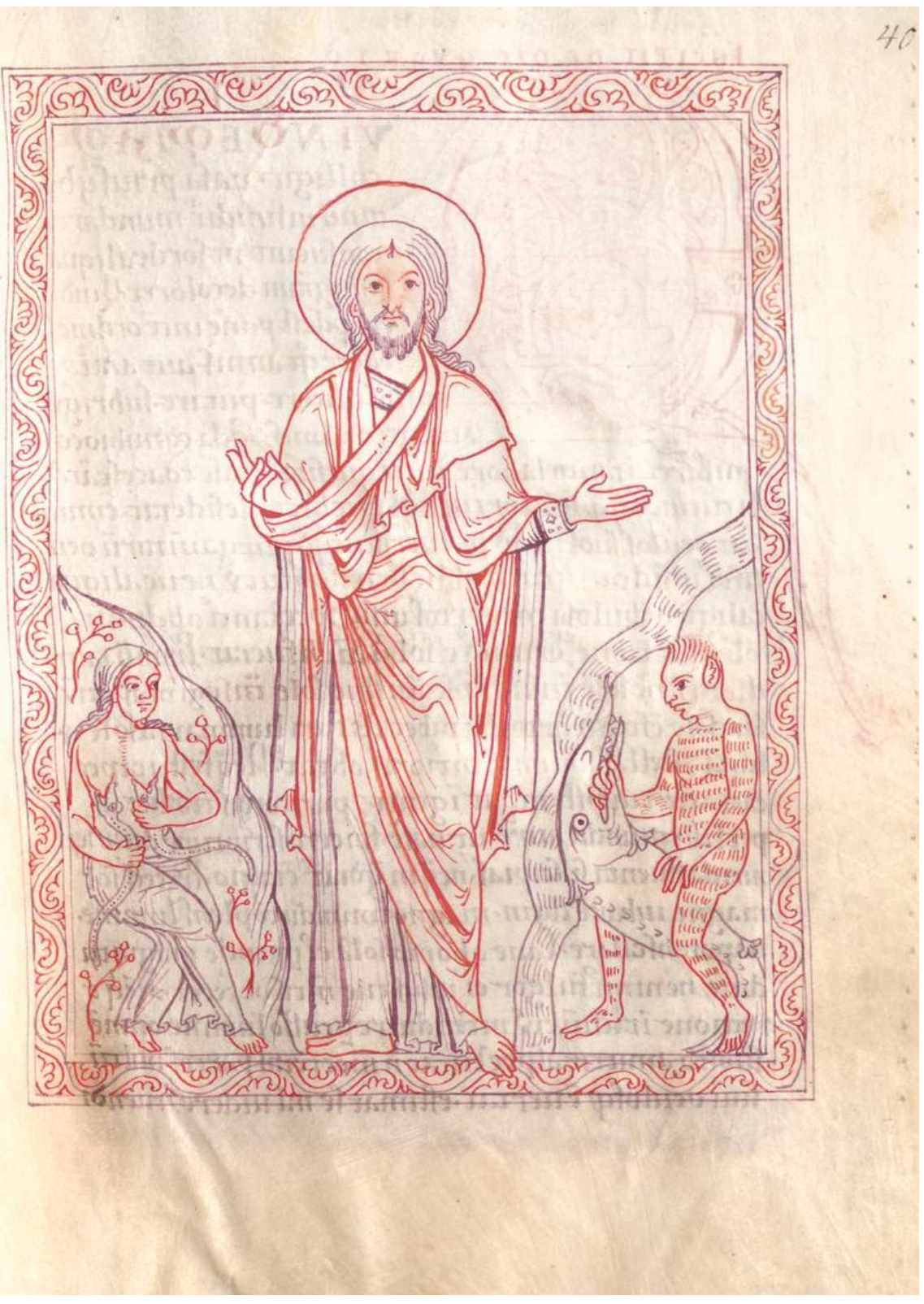

Fig. 1: Clm 14399, fol. 40, München, Bayerische Staatsbibliothek htpp://daten.digitale-sammlungen.de/ bsb00046506/image89, (12/12/2016)
Si en la iconografía medieval existe una representación que ilustra de manera clara la asociación entre mujer, tentación, sexo y pecado esa es sin lugar a dudas la femme-aux-serpents, que resulta ser la imagen predilecta para ilustrar el pecado de la lujuria en el imaginario de la Edad Media y que se va a utilizar además como exemplum para dejar muy clara la naturaleza pecadora de la mujer.

En los últimos años estudios como los de Amanda Luyster o Raphael Guesuraga están tratando de precisar de manera más exhaustiva su significación ${ }^{5}$, pero aunque esta imagen pueda aludir a la lujuria en general, a las malas madres en particular o estar relacionada con la campaña que se desata a lo largo del siglo XI contra el nicolaísmo, dichas especificaciones no dejan de ser variantes sobre una misma consideración de la mujer claramente negativa y merecedora de acciones punitivas por su propia naturaleza.

Quien contempla alguna de estas representaciones por primera vez no puede evitar sentir un escalofrío y una sensación física, ya que evocan un tormento, un suplicio tan intensamente doloroso como repulsivo ${ }^{6}$

5 LUYSTER, A.: “The Femme-aux-Serpents at Moissac: Luxuria (Lust) or a Bad Mother?", in: Between Magic and Religion: Interdisciplinary Studies in Ancient Mediterranean Religion and Society. Oxford, Rowman\&Littlefield Publishers, 2001, pp. 165-191. GUESURAGA, R.: "La mujer son serpientes y sus dudosas relaciones con la lujuria", Románico, no 17, 2013, pp. 17-23. Del mismo autor: "La mujer con serpientes y los clérigos nicolaítas", Románico, no 18 (2014) pp. 16-23. En mi opinión la amplia difusión de la imagen de la femme aux serpents se encuentra claramente asociada a importancia que la lujuria tiene como uno de los pecados más reprobados y condenados del momento, pecado que, a mi juicio, comprende actitudes como las de las "malas madres" o las de las mujeres que tienen relaciones con eclesiásticos.

6 WEISBACH, W.: Reforma religiosa y arte medieval. La influencia de Cluny en el Románico occidental. Madrid, Espasa-Calpe, 1949, p. 90 ya señaló que uno de los objetivos de la figura de la femme aux serpents era despertar la mayor repugnancia posible y que para ilustrar la lujuria se creó un tipo iconográfico de un carácter extremadamente odioso. 
Además, para incrementar aún más esa sensación, el castigo corporal se centra en algunas de las partes más sensibles del cuerpo femenino, los pechos y la vulva, mordidos o succionados en la mayor parte de las ocasiones por serpientes o sapos que al mismo tiempo pueden trepar y enroscarse en otras partes del cuerpo. Estamos por lo tanto ante una imagen que inmediatamente activa los cinco sentidos de quien la contempla. Esta estrategia sin embargo no es algo nuevo, ya que el objetivo de conseguir evocar una sensación física a través de los suplicios corporales es algo absolutamente presente en los textos y las representaciones medievales. Además son estrategias pictóricas, en el sentido de figurativas, del arte popular de todas las épocas? ${ }^{7}$.

No es el propósito de este estudio abordar el proceso de sistematización de los pecados en los siglos altomedievales ${ }^{8}$, pero sí el de destacar alguno

7 A ello se refiere LYMAN, TH.W.: " Motiv et narratif. Vers una typologie des thémes profanes dans la sculpture monumentale de Los Romerías", Cahiers de Saint Michel de Cuxa, no 10, 1979, p. 69.

8 En un principio no se calificaron como pecados, ya que no se consideraban faltas que suponían una acción consciente y voluntaria, sino más bien como tendencias que llevaban al mal. "Se les ha llamado pensamientos, espíritus, con la idea de que su origen es demoníaco o simplente vicios". SOLIGNAC, A.: "Peches capitaux", dans: Dicctionnaire de spiritualité ascétique et mistique. París, M. Viller, Tomo XII, 1, 1984, pp. 853-862. Los denominados vicios o pecados capitales ocuparon un lugar importante en los estudios de los Santos Padres de la Iglesia oriental y occidental desde el siglo III. Entre ellos destacan los de Clemente de Alejandría, Tertuliano u Orígenes y tratados del siglo IV como los de Lactancio, San Ambrosio o San Juan Crisóstomo. El intento de sistematizarlos corresponde a Evagrio el Póntico en dos obras: Antirrhéticos y Prácticos, esta última incluida en su Monachikos, y a su discípulo Juan Casiano en sus Instituciones Cenobíticas y en los libros VII y VIII de su obra Collactiones Patrum. Para toda esta cuestión ver: CASAGRANDE, C; VECCHIO, S.: Histoire des péchés capitaux au Moyen Âge. París, Flammarion, 2003, quienes señalan que la idea de vicios o pecados capitales, ausente en la Biblia y en las primeras reflexiones patrísticas, se define por primera vez en las páginas de estos dos autores. Las referencias a los dos monjes orientales figuran en la mayor parte de los autores que se han ocupado de esta de los textos más significativos en relación a la imagen que estamos analizando. En este sentido una de las obras más influyentes de la cultura medieval, Moralia in Job del monje y papa san Gregorio, expone una lista de los siete pecados capitales en la que la Fornicación de los autores anteriores se ha transformado ya en Luxuria ${ }^{9}$. En la tradición medieval los efectos perniciosos de la lujuria afectan a todo el cuerpo y por ello todos los órganos responsables de la actividad sensorial se ven implicados. La lujuria es por lo tanto el único vicio que se sirve de los cinco sentidos del cuerpo humano y que en una progresión creciente va afectando a la vista,

temática y su referencia sería excesivamente larga para estas páginas. Entre las monografías más recientes con aportaciones de señalados especialistas: NEWHAUSER, B. y R. (ed.): In the Garden of Evil. The Vices and Culture in the Middle Ages. TorontoOntario, Papers in Mediaeval Studies, 18, 2005. Desde un punto de vista básicamente histórico: Los caminos de la exclusión en la sociedad medieval: pecado, delito y represión. XXII Semana de Estudios Medievales (Nájera, 2011), Logroño, Instituto de Estudios Riojanos, 2012.

9 Moralia in lob, XXXI, XLV, 87. SAN GREGORIO MAGNO.: Commento morale a Giobbe. Vol. 4 (XXVIII-XXXV), Roma, Bibliotheca Gregorii Magni/ Cittá Nuova Editrice, 2001, pp. 322 (edición bilingüe latín-italiano). Como Fornicación aparece en las listas de Evagrio el Póntico y de Juan Casiano, término que en principio indica la unión carnal fuera del matrimonio, pero que por metonimia acabará designando a todos los pecados ligados a la sexualidad. En la lista de San Gregorio el vicio o pecado cambia de nombre y se denomina ya Luxuria, término excesivamente vago que designa genéricamente exceso y más concretamente inclinación exacerbada hacia el disfrute de los placeres de los sentidos. Terminará por prevalecer sobre la fornicación que tiene un sentido más específico y restringido. San Gregorio considera la Luxuria un vicio carnal, una excitación de los órganos sexuales provocada por la presión de un vientre hinchado debido al exceso de alimento, pero su campo de actuación no se limita únicamente a las zonas inferiores y viles del cuerpo humano, sino que se extiende a todo el cuerpo. La luxuria además propicia la ceguera mental, la ligereza, la inconstancia, la precipitación, el amor a sí mismo, el odio de Dios, el afecto al mundo, a lo terrenal, y el horror o la desesperación ante la llegada del destino final: "De luxuria, caecitas mentis, inconsideratio, inconstantia, praecipitatio, amor sui, odium Dei, affectus praesentis saeculi, horror autem uel desperatio futuri generatur". Moralia in lob, XXXI, XLV, 88. 
el olfato, el gusto, el oído y culmina con el tacto ${ }^{10}$. De ahí que una de las estrategias fundamentales para vencer las tentaciones fuera la privación sensorial, por lo que la vinculación de la Luxuria, vicio carnal, con el exceso de alimento, ya señalada en san Gregorio, va a propiciar que en numerosos textos de los primeros siglos cristianos uno de los instrumentos primordiales para disminuir e intentar erradicar el deseo sexual resultara ser la privación de alimento, sacrificio que junto al sufrimiento corporal se recomendaba encarecidamente a los religiosos ${ }^{11}$.

10 CASAGRANDE, C; VECCHIO, S.: Histoire des... Op. cit., pp. 234-235. Recogido también en MARTÍNEZ DE LAGOS, E.: "La femme aux serpents", evolución iconográfica de la representación de la lujuria en el Occidente europeo medieval". Clio\&Crimen, no 7, 2010, pp. 137-158. Me parece sumamente interesante destacar este aspecto porque estudios recientes que actualizan y aportan nuevos enfoques metodológicos para el análisis de las obras medievales, están subrayando el papel que tuvo la activación de los sentidos para transmitir ideas teológicas. En muchas ocasiones el propósito que guiaba la realización de estas obras artísticas era una re-presentación, un volver a presentar a través de las imágenes los contenidos de los discursos teológicos que se transmitían en la liturgia. Se instaba a los fieles a creer en las imágenes a partir de la activación sensorial de los cinco sentidos, tanto en los rituales de la liturgia, como en la contemplación de dichas representaciones y en el caso de la imagen que nos ocupa dicha posibilidad parece ser bastante clara. Uno de los autores que más se ha ocupado de la activación de los sentidos en la liturgia y el arte es PALAZZO, E.:"Art, Liturgy and the Five Senses in the Early Middle Ages", Viator 41(1), 2010, pp. 25-56. Del mismo autor: "Visions and Liturgical Experience in the Early Middle Ages", in: Looking Beyond. Visions, Dreams and Insights in Medieval Art and History. Princenton University, 2010, pp. 15-29. "Les cinq sens au Moyen Age. Etat de la question et perspectives de recherche", Cahiers de civilisation médiévale, 55, 2012, pp. 339-366. "Voir et entendre les chants de la messe", Codex Aquilarensis 28, 2012, pp. 219-230. Y más extensamente en su reciente estudio: L'invention chrétienne des cinq sens dans la liturgie et l'art au Moyen Âge. París, Les Éditions du Cerf, 2014. La consideración de los sentidos también ha sido abordada por KESSLER, H .L.: Spiritual Seeing. Picturing God's Invisibility in Medieval Art. Philadelphia, 2000. Y del mismo autor: "Speculum", Speculum, 86, 2011, pp. 1-41.

11 A la relación luxuria y gula se refiere PILOSU, M.: La Donna, la Lussuria e la Chiesa nel Medioevo. Génova, Edizioni Culturali Internazionali, 1989, pp. 42-54. Ver también: ROUSSELLE, A. Porneia. De la maîtrise du corps á la privation sensorielle. Ile-IVe siécle
Si el pecado de lujuria tiene como característica principal su relación directa con el cuerpo, y aquí no podemos olvidar las cartas paulinas ${ }^{12}$, no nos puede extrañar que la representación de este castigo sea tan rotunda atormentando el cuerpo con suplicios que afectan a las partes femeninas consideradas explícitamente erógenas. En este sentido y considerando que el propio San Pablo dejó muy claro que "a los pecadores les espera un final conforme a sus acciones" ${ }^{13}$ sorprende el escaso porcentaje de hombres cuyos órganos sexuales son atacados por reptiles o batracios. Quizás la imagen más explícita sea el relieve de una dovela conservada en el Museo de la Catedral de Santiago de Compostela en la que un reptil de naturaleza indefinida muerde el pene de un personaje al que varias serpientes parecen atacar también la cabeza y en Francia se han contabilizado en torno a una decena de ejemplos de hombres torturados por serpientes $u$ otros reptiles, pero lo habitual es que este castigo incida en otras partes de su cuerpo por lo que dichas representaciones no parecen estar vinculadas a los pecados de la carne ${ }^{14}$.

"Sed fecundos y multiplicaos" dice Dios en la primera versión del Génesis, algo que, como sabemos, implica la unión carnal. Entonces ¿por qué esa aversión hacia el cuerpo y el sexo? El cristianismo siempre ha mostrado una gran ambivalencia en relación al cuerpo, lo reprime ya que el cuerpo

de l'ère chrétienne. París, 1983.

12 "Huid de la lujuria. Todo pecado cometido por el hombre queda fuera del cuerpo, pero el lujurioso peca contra su propio cuerpo". 1 Corintios 6,18 . "¿Quién me librará de este cuerpo, que es portador de muerte?". Romanos 7, 24. "Ahora bien, si Cristo está entre vosotros, aunque el cuerpo esté sujeto a la muerte a causa del pecado, el espíritu vive por la fuerza salvadora de Dios". Romanos 8, 10.

132 Corintios 11,15

14 WEIR, J.; JERMAN, J.: Images of Lust. Sexual carvings on Medieval Churches. Londres, B.T. Batsford Ltd, 1986, pp. 74-79 y mapa de la p. 131. GUESURAGA, R.: "Los hombres con la cabeza devorada por dragones, una representación del enemigo simoniaco en la escultura románica. Sinopsis de una hipótesis”, Románico, no 11, 2010, pp. 24-31. 
es despreciado, condenado y humillado, es considerado "abominable vestimenta del alma" por san Gregorio y la salvación pasa por la penitencia corporal, pero por otro, y con la encarnación de Dios en el cuerpo de Cristo para redimir a la humanidad, lo glorifica. Sin embargo lo que va a prevalecer es el desprecio hacia el cuerpo, cuerpo que se va a considerar la prisión y el veneno del alma y en ese sentido la lujuria es uno de los vicios más perniciosos, ya que es el motor que anima algunas de las actividades más peligrosas e inmundas del cuerpo e incluso se va a considerar origen de algunas de sus enfermedades más repugnantes ${ }^{15}$.

La valoración de la castidad y de la virginidad que hace el cristianismo es lo que va a dar el impulso definitivo a la depreciación del cuerpo en general ${ }^{16}$

15 Para la renuncia al cuerpo durante los siglos medievales ver: LE GOFF, J.; TRUONG, N.: Una historia del cuerpo en la Edad Media. Barcelona, Paidós, 2005, pp. 34-35. Para la vinculación de la lujuria con enfermedades como la lepra y su consideración de vicio fétido y nauseabundo CASAGRANDE, C.; VECCHIO, S. Histoire des... Op. cit., pp. 235237.

16 San Isidoro de Sevilla señala que el cuerpo humano se denomina así porque está destinado a la corrupción "corpus dictum, eo quod corruptum perii (llamado cuerpo porque perece por corrupción)". Etimologías, XI, 1, 14. SAN ISIDORO DE SEVILLA.: Etimologías. J. OROZ RETA y M.A. MARCOS CASQUERO (ed.) Madrid, Biblioteca de Autores Cristianos, 1983. De hecho la moralidad cristiana está dirigida a asegurar la salud espiritual del hombre, no la salud corporal. De ahí que casi todas las actividades dirigidas al bienestar físico de los hombres sean consideradas vanidades de la carne que distraen el alma de su búsqueda de la perfección interior. GIORDANO, O.: Higiene y buenas maneras en la Alta Edad Media. Madrid, Gredos, 2001, pp. 21-22. La tendencia a la renuncia al cuerpo y a devaluar sus funciones hunde sus raíces en la Antigüedad, donde algunas corrientes de rigorismo ético y de rechazo a los placeres materiales proponían soluciones ascéticas y abstencionistas, sobre todo de índole sexual. Este hecho ya ha sido puesto de manifiesto por distintos investigadores que vinculan su difusión a diversas escuelas de carácter estoico, cuyas ideas, transmitidas a través de Cicerón y Séneca, comparten algunos rasgos similares con la ascesis cristiana. Las corrientes estoicas tuvieron una difusión significativa entre las élites romanas y su vertiente ética influye en autores cristianos como Tertuliano o San Jerónimo. A ello se refieren: SERRATO, M.: Ascetismo femenino en Roma. Estudios sobre San Jerónimo y y de la sexualidad en particular, aspectos que aparecen ya claramente reflejados en las epístolas paulinas ${ }^{17}$ y en los escritos de los Padres de la Iglesia y que se consolidarán definitivamente con el ideal ascético que propugnan los primeros tratadistas cristianos ${ }^{18}$. La corriente de enaltecer la virginidad que se había manifestado en el Nuevo Testamento y que continúa en la Patrística va a tener una influencia considerable en los sectores eclesiásticos durante los siglos medievales, hasta el punto de que

San Agustín. Universidad de Cádiz, 1993, p. 50. VECCHIO, S.: "Passions de l'âme et péchés capitaux: les ambigüités de la culture médiévale", in: FLÜELER, C.; ROHDE, M (ed.): Laster im Mittelalter/ Vices in the Middle Ages. . Berlin-NewYork, 2009, p. 46. LE GOFF, J.; TRUONG, N. Una historia... Op. cit., pp.43-44. CASANOVA, E.; LARUMBE, Ma.A.: La serpiente vencida. Sobre los orígenes de la misoginia en lo sobrenatural. Prensas Universitarias de Zaragoza, 2005, pp. 330-333. TOLDRÁ I VILARDELL, A.: Asmodeu. Dona, dimoni y sexe a l'edat mitjana. Universitat de Valencia, 2011, p. 13. Entre los distintos estudios que abordan el giro que se produce en la moral sexual del Imperio Romano desde la segunda mitad del siglo I: PUENTE, G.: Ideología e Historia: EI fenómeno estoico en la sociedad antigua. Madrid, Siglo XXI, 1974. VEYNE, P.: La famille et I'amour sous le haut Empire romain. Annales E.S.C., 1978. FOUCAULT, M.: Histoire de la sexualité. Tomo II: L'Usage des plaisirs. París, Gallimard, 1984. ROBERT,J. N.: Eros romano: Sexo y moral en la antigua Roma. Madrid, Editorial Complutense, 1999.

17 "Ahora bien, sentir según los propios apetitos lleva a la muerte; sentir conforme al Espíritu conduce a la vida y a la paz", "Así pues los que viven entregados a sus apetitos no pueden agradar a Dios", "porque si vivís según ellos, ciertamente moriréis". Romanos 8 , versículos 5,8 y 13 . "Quisiera yo que todos los hombres siguiesen mi ejemplo", "A los solteros y a las viudas les digo que es bueno que permanezcan como yo. Pero si no pueden guardar continencia, que se casen. Es mejor casarse que abrasarse". 1 Corintios 7, 7 -9. Sobre el alcance de las palabras de Pablo en relación a este tema: BENEDETTO, P.: Matrimonio e continenza nel cristianesimo delle origini. Studi su I Cor. 7, 1-40. Brescia, 1979. CASANOVA, E.; LARUMBE,Ma. A.: La serpiente. Op. cit., pp. 323-328.

18 Desde el siglo III, siglo del despertar de la literatura cristiana latina, van a proliferar escritos de los tratadistas cristianos que promueven la ascesis y exaltan la virginidad. Entre ellos destacan el Apologeticum, el De exhortatione castitatis o el De monogamia de Tertuliano, que si bien se refieren sobre todo al matrimonio ponen de manifiesto su valoración de la continencia y sobre todo su De virginibus velandis, donde realiza una 
algunos autores llegaron prácticamente a condenar el matrimonio. Los ataques fueron tan fuertes que de no ser tan evidente su necesidad, ya que la procreación exigía la unión carnal, casi hubiera sido considerado como algo herético. Se extendió así la idea del matrimonio como remedium concuspiscentiae, como algo relegado a aquellos que no aspiran a un estado de perfección evangélica ${ }^{19}$. Puesto que la castidad no puede hacerse extensiva a los laicos, porque la procreación es necesaria, la

exaltación rotunda de la virginidad. Otras figuras destacadas son Cipriano de Cartago, Clemente de Alejandría, Lantancio, Ambrosio, Juan Crisóstomo u Orígenes de Alejandría, cuyo ascetismo le llevo a la autocastración según narra Eusebio de Cesarea en su Historia Eclesiástica. En el Sínodo de Elvira, el más antiguo de los celebrados en Occidente y que tuvo lugar a caballo entre el siglo III y el siglo IV se señala la excelencia del estado virginal y su preeminencia sobre la condición matrimonial, aspectos estos a los que se refiere en el canon XXXIII. SERRATO, M. Ascetismo femenino... Op. cit., pp. 15-34.

19 Entre los detractores más agresivos debemos destacar sin duda a San Jerónimo, monje de Belén y uno de los Padres de la Iglesia latina, quien en su Adversus Jovinianum establece un combate furioso contra la mujer y el matrimonio, señalando que el matrimonio en sí es el mal y que el marido, forzosamente fornicador, se convierte además en adúltero si se le ocurre amar a su mujer con cierto calor, haciendo de ella una prostituta. DUBY, G.: El Caballero, La Mujer y El cura. El matrimonio en la Francia feudal. Madrid, Taurus, 1982, p. 26. A San Jerónimo se refiere también: D'ALVERNY, M.TH.: "Comment les théologiens et les philosophes voient la femme", Cahiers de Civilisation Médiévale, no 20,1977, pp. 105-129, artículo donde realiza un estudio muy exhaustivo de la consideración de la mujer en los tratadistas medievales. Para esta obra de San Jerónimo ver: DELHAYE, PH.: "Le dossier antimatrimonial de I "Adversus Jovinianum" et son influence sur quelques écrits latins du XIle siécle", Mediaeval Studies, 13, 1951, pp. 65-86. Más recientemente: MARCOS SÁNCHEZ, M. del M.: "La visión de la mujer en San Jerónimo a través de su correspondencia", en: La mujer en el Mundo Antiguo. Actas de las V Jornadas de Investigación Interdisciplinar, Madrid, 1986, pp. 315-322 y de la misma autora: "Caracterización del sexo femenino en la correspondencia de San Jerónimo", en: VII Congreso Español de Estudios Clásicos, Vol. 3, 1989, pp. 211-216. Para la obra completa de este autor: VV.A.A. Obras completas de San Jerónimo. Biblioteca de Autores Cristianos. Madrid, 1999. Para un estado de la cuestión sobre el tema que estamos tratando: MARTíNEZ DE LAGOS, E.: Ocio, diversión y espectáculo en la escultura gótica. Bilbao, Universidad del País Vasco, 2007, pp. 449-465. solución pasa entonces por permitir la actividad sexual únicamente dentro del matrimonio, sólo con el fin de procrear y además con numerosas restricciones, por eso el matrimonio es sólo una concesión a los que no

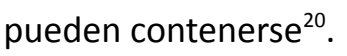

En el año 999 el abad Abbon de Fleury, hoy Saint-Benoît-sur-Loire, habla de una escalera jerárquica para los tres órdenes que componen la Iglesia: monjes, clérigos y laicos: "Entre los cristianos de ambos sexos sabemos que existen tres órdenes 0 , mejor dicho, tres grados. El primero es el de los laicos, el segundo el de los clérigos y el tercero el de los monjes. Aunque

20 CASAgRANDE, C.; VeCCHIO, S. Histoire des... Op. cit., p. 259. En este sentido hay que señalar que la Iglesia intentará imponer a los laicos una moral sexual restrictiva que se manifiesta en la práctica a través de manuales destinados a los confesores, los penitenciales, donde aparecen enumerados los pecados de la carne asociados a las penas y penitencias que les corresponden. En estos penitenciales se condena toda práctica sexual considerada "no normal" y que no tenga como único fin la procreación posturas extrañas, mantener relaciones durante la menstruación o el embarazo, masturbaciones, felaciones, adulterio, sodomías, relaciones con monjes o monjas etc, y se exige respetar la prohibición de mantener relaciones sexuales en aquellos períodos del año litúrgico que impone la iglesia. Hay textos que incluyen prácticas que parecen haber surgido más bien de los delirios de los teólogos que de la imaginación de los casados a los que probablemente no se les ocurrirían semejantes comportamientos. Muy ilustrativo resulta el Libri Decretorum del obispo Buscardo de Worms de comienzos del siglo XI, en el que se refiere a las mujeres que se beben el esperma del marido para que las quiera más gracias a sus prácticas diabólicas o a las que se introducen un pez vivo en su sexo y lo mantienen ahí hasta que muere para después cocinarlo y dárselo al marido para que "arda aún más por ellas". Un comentario extenso sobre los distintos capítulos del penitencial del obispo de Worms en: HERRERO MARCOS, J.: La lujuria en la iconografía románica. Palencia, Cálamo, 2011, pp. 74-95. Ver También: LE GOFF, J.; TRUONG, N.: Una historia del... Op. cit., pp. 40-41. NUÑO GONZÁLEZ, J.: "Hacia una visión de la iconografía sexual: escenas procaces y figuras obscenas", en: Poder y seducción de la imagen románica. Aguilar de Campoo, Fundación Santa María la Real, 2005, pp. 219-220. Para toda esta cuestión resulta muy ilustrativo el estudio de VERDON, J. El Amor en la Edad Media. La carne, el sexo y el sentimiento. Barcelona, Paidós, 2008, pp. 26-42. 
ninguno de los tres esté libre de pecado, el primero es bueno, el segundo mejor y el tercero, excelente. Por lo que respecta a la condición conyugal, ésta es admitida por indulgencia para evitar que el hombre, en la edad en que las tentaciones debidas a la fragilidad de la carne son fuertes, caiga en una situación todavía peor" ${ }^{21}$. Ya lo había dicho san Pablo "más vale casarse que abrasarse". Como vemos, dicha escala jerárquica está basada primordialmente en la renuncia a los placeres terrenales y más concretamente a los carnales, la condición carnal es mala y cuanto más se aleja uno de la carne más perfecto se es.

Que la visión negativa del matrimonio está estrechamente vinculada a la unión carnal es algo fuera de toda duda, unión carnal que en el Paraíso era intachable y exenta de toda sensualidad, pero que como consecuencia del Pecado Original se convierte en un acto vicioso y pecaminoso siempre sometido al apetito sexual, hecho éste que resulta tremendamente significativo para el tema que estamos tratando. El propio san Jerónimo, llevado por un riguroso ascetismo, no duda de que Adán y Eva permanecieron vírgenes en el Paraíso. Sus cuerpos sólo se unieron después de La Caída, en la maldición, de ahí que para él todas las nupcias sean malditas ${ }^{22}$. San Gregorio por su parte opina que desde el Pecado Original no hay copulación sin placer y que por lo tanto el matrimonio está indiscutiblemente mancillado. Desde entonces la ley primitiva del

21 ABBON DE FLEURY (Abbonis Floriacensis abbatis) "Apologeticus ad Hugonem et Rodbertum reges Francorum". PL, 139, 463, en: VAUCHEZ, A.: La espiritualidad del Occidente medieval. Madrid, Cátedra, 1985. p. 48. WEISBACH, W.: Reforma religiosa... Op. cit., pp.26-27. Una división similar había sido ya realizada por San Gregorio, quien inspirándose en un pasaje del profeta Ezequiel (XIV, 14) dividió a los cristianos en tres categorías: conjugati (los esposos), continentes (los religiosos) y predicatores (los clérigos seculares), estableciendo que la jerarquía de los diferentes estados de vida tiene que ver con la condición carnal. Ver también VAUCHEZ, A.: Les laïcs au Moyen Age. Practiques et experiences religieuses. París, Les Éditions du Cerf, 1987, pp. 49-53.

22 DUBY, G.: El matrimonio... Op. cit., p. 26. Para san Jerónimo y su consideración del ascetismo mundano ver: SERRATO, M.: Ascetismo femenino... Op. cit., pp.36-46. matrimonio ha sido "transgredida" y por ello todos los hombres y mujeres que no han rechazado el matrimonio son inferiores y despreciables ${ }^{23}$. Ahora bien san Gregorio tiene un inspirador, ya que la asociación de la concupiscencia carnal con el Pecado Original tiene su base en el discurso que san Agustín desarrolla en la Ciudad de Dios $^{24}$. Como apunta JeanClaude Schmitt ver en el pecado de soberbia de los primeros padres un pecado corporal e incluso sexual, un efecto de la concupiscentia carnis o de la luxuria, como se dirá más tarde, es una tendencia ya explícita en san Agustín $^{25}$.

"Entonces se les abrieron los ojos, se dieron cuenta de que estaban desnudos" (Gn, 3,7). San Agustín hace referencia a esta cuestión en el Libro decimocuarto de su extensa obra, donde habla "de la desnudez de los primeros hombres y de cómo, después que pecaron, les pareció torpe y vergonzosa" ${ }^{26}$. Según su discurso antes del Pecado Original los primeros hombres estaban desnudos, pero no se avergonzaban, no porque dejasen de ver su desnudez, sino porque ésta no era aún vergonzosa ya que la carne no movía el deseo contra la razón. En el Paraíso los órganos de la generación eran movidos por la voluntad, no excitados por la libido y al

23 Regula Pastoralis, III, 27; PI 77, 102

24 "Así que dos amores fundaron dos ciudades; es a saber: la terrena, el amor propio, hasta llegar a menospreciar a Dios, y la celestial, el amor a Dios, hasta llegar a desprecio de sí propio. La primera puso su gloria en sí misma, y la segunda, en el Señor; porque la una busca el honor y gloria de los hombres, y la otra, estima por suma gloria a Dios". SAN AGUSTín.: La ciudad de Dios. Libro XIV. Capítulo XXVIII. MORÁN O.S.A. J. Obras de San Agustín. La Ciudad de Dios. Madrid, Biblioteca de Autores Cristianos, 1964.

25 SCHMITT, J. C.: "Cuerpo y alma", en: Diccionario razonado del Occidente Medieval. Madrid, Akal, 2003, p. 191. También COLIN-GOGUEL, F.: L'image de l'Amour charnel au Moyen Age. París, Seuil, 2008, p.10.

26 SAN AGUSTín.: La ciudad.... Op. cit., Libro XIV, Capítulo XVII. Recogido también en COLIN-GOGUEL, F.: L'image... Op. cit., p. 64. 
hombre le era posible tener sujetos los miembros inferiores, facultad que perdió por su desobediencia ${ }^{27}$.

Para san Agustín el pecado cometido por los primeros padres fue un pecado de desobediencia y de soberbia, pero también es cierto que la primera consecuencia de ese pecado fue precisamente que fueron conscientes de su desnudez y de la desobediencia de la carne, puesto que ya no podían controlar sus deseos o apetitos carnales. Fue un pecado enorme que corrompió la naturaleza humana trascendiendo hasta sus más remotos descendientes. A ello debemos añadir además que la unión carnal es la vía de la procreación, por lo que después del Pecado Original los hombres no sólo nacen pecadores, sino que, y esto es casi más grave, nacen como consecuencia de un acto que es pecaminoso en sí mismo y que es el modo a través del cual esa primera falta es transmitida a toda la humanidad ${ }^{28}$. Por ello y desde ese momento la corrupción y el vicio afectan de manera directa al ejercicio de la sexualidad que se convierte en un deseo exacerbado y desordenado.

La lectura que la Edad Media hizo de los postulados agustinianos fue simplificándose y radicalizándose de tal manera que la concupiscencia carnal se entendió como motivo fundamental del pecado de los primeros padres. Se consideró, no una consecuencia del Pecado Original, sino el pecado mismo, por lo que sexualidad y Pecado Original terminaron por identificarse: "el pecado original, fuente de la desdicha humana y que figura en el Génesis como un pecado de orgullo y desafío del hombre hacia

27 Idem. Cápitulo XXIV. Esta cuestión se analiza también en: MORAL DE CALATRAVA, P. La mujer imaginada. La construcción cultural del cuerpo femenino en la Edad Media. Murcia, Nausicaä, 2008, pp. 18-19.

28 CASAGRANDE, C.; VECCHIO, S.: Histoire des... Op. cit., p. 232 haciendo referencia a los capítulos XV-XXVI del libro XIV de La Ciudad de Dios de san Agustín.
Dios, se convierte en la Edad Media en un pecado sexual" ${ }^{29}$. Y por ello la sexualidad se convierte en el campo de acción de una serie de actividades diversas y pecaminosas unificadas en el interior de un vicio denominado Luxuria $^{30}$.

Si repasamos los textos de las Sagradas Escrituras, de los Padres de la Iglesia y de los primeros tratadistas cristianos la mayor parte de los humanos que describen y abordan los peligros de este vicio son hombres, los que sucumben ante su poderosa atracción son hombres y los que consiguen vencer a su tentación también. $Y$ sin embargo, a la hora de representar el horripilante castigo reservado a la lujuria nos encontramos con que un porcentaje significativamente elevado de los humanos castigados son mujeres $y$, de hecho, entre los diversos temas iconográficos que aluden a la lujuria de una manera más o menos taxativa ${ }^{31}$ es la femme

29 LE GOFF, J.; TRUONG, N.: Una historia... Op. cit., pp. 12-13.

30 CASAGRANDE, C.; VECCHIO, S.: Histoire des... Op. cit., p. 233

31 El catálogo de imágenes asociado a este vicio puede incluir motivos muy diversos: parejas en el lecho, parejas abrazándose y besándose, relaciones sexuales explícitas, mujeres y hombres exhibicionistas destacando los personajes itifálicos y las conocidas sheela-na-gigs, gestos procaces, el espinario, las sirenas, escenas de homosexualidad bestialismo (bastante más escasas), mujeres dando a luz e incluso escenas juglarescas con danzarinas contorsionistas. La bibliografía es muy abundante a este respecto, pero entre los estudios hasta ahora no citados destacamos: RUIZ MONTEJO, I.: "La temática obscena en la iconografía del románico rural”, Goya, no 147, 1978, pp. 136-146; SAUGNIEUX, J.: "Culture religieuse et culture profane. Les representations de la luxure dans I'art francais du XIle siécle", dans: Cultures populaires el cultures savantes en Espagne du Moyen Age aux Lumiéres. París, CNRS, 1982, pp. 80. DEL OLMO GARCÍA, A.; VARAS VerANO, B.: Románico erótico en Cantabria. Palencia, 1988. PÉREZ CARRASCO, F. J.: "La iglesia contra la carne. El programa contra la lujuria esculpido en la iglesia de Cervatos", Historia 16, no XVI, 1992, pp. 55-65; del mismo autor: "Iconografía obscena en la escultura románica burgalesa", en: III Jornadas burgalesas de Historia Medieval. Burgos en la Plena Edad Media. Burgos, 1994, pp. 731-741. "Lujuria, redención y conciencia individual en un programa iconográfico en torno a 1200. La iglesia de Revilla de Santullán (Palencia)", Actas del IX Congreso Español de Historia del Arte. León, 1992, 
aux serpents el motivo más difundido en todo el Occidente medieval ${ }^{32}$. Sabemos claramente quién es la gran perdedora del Pecado Original, a quién se dirigió la serpiente para tentarla y quién fue la instigadora de la desobediencia hacia Dios: "Y no fue Adán el que se dejó engañar, sino la mujer, que seducida, incurrió en la transgresión" (I Timoteo 2, 14). Pero Eva, la tentadora, la pecadora, la gran culpable, ${ }^{33}$ ya tenía todas las de perder desde el principio, puesto que los tratadistas cristianos no hacen

pp. 77-90. CUADRADO LORENZO, Ma. F.: "Tres esculturas de Leire y sus relaciones con temas escatológicos", Príncipe de Viana, no 199, 1993, pp. 229-245. ARAGONÉS ESTELLA, E.: La imagen del mal en el románico navarro. Pamplona, Gobierno de Navarra, 1996. CARRILLO LISTA, Ma.P.; FERRÍN GONZÁLEZ, J. R.: “Algunas representaciones de vicios en el románico gallego: la lujuria", Anuario Brigantino, no 19,1996, pp. 235-244. De los mismos autores: "La figura de la mujer con serpientes y el castigo de la lujuria en el Arte Románico", en: La Vida Cotidiana en la España Medieval. Actas del VI Curso de Cultura Medieval. Madrid, 1998, pp. 391-408. GÓMEZ GÓMEZ, A.: El protagonismo de los otros. La imagen de los marginados en el arte románico. Bilbao, 1997. Del mismo autor: "La iconografía del parto en el arte románico hispano", Príncipe de Viana, no 213, 1998, pp. 79-101. DEL OLMO GARCíA, A.: Iconografía sexual en el Románico. Salamanca, 1999. PACE, V.: "Immagini della sessualitá nel Medioevo italiano", en: Medioevo: immagini e ideologie. Atti del Conv. int. di studi (Parma 2002), Milán, Electa, 2005, pp. 630-643. ANGHEBEN, M.: Les chapiteaux romans de Bourgogne. Thémes et programmes. Brepols, Turnhout, 2003, pp. 330-336 y 345-346 para el tema que estamos tratando. RODRÍGUEZ BARRAL, P.: "Reflexiones sobre el castigo de la avaricia y la lujuria a propósito de su representación en la escultura románica catalano-aragonesa", Codex Aquilarensis, no 21, 2005, pp. 628. NUÑO GONZÁLEZ, J.: Hacia una visión... Op. cit., pp. 193-226. MONTEIRO ARIAS, I.: "Las formas del pecado en la escultura románica castellana. Una interpretación contextualizada en relación con el Islám”, Codex Aquilarensis, no 21, 2005, pp. 51-83. DIMANUEL JIMÉNEZ, M.: "Iconografía erótica en la Edad Media", Liceus, Portal de Humanidades, 2006. VV.AA.: Medieval Obscenities. Suffolk-Rochester, 2006. MOLINIÉ, S.: "L'image de la femme luxurieuse et tentatrice dans la sculpture romane du Midi de la France", Revue d'Auvergne, no 586, 2008, pp. 109-124. POZA YAGÜE, M.: "La lujuria", Revista Digital de Iconografía Medieval, vol. II, no 3, 2010, pp. 33-40. De la misma autora: "Las portadas de los prioratos cluniacenses de Tierra de Campos en tiempos de Alfonso VI: una iconografía de corte monástico para una manifestación pública", Anales de Historia del Arte, 2011 (Volumen Extraordinario 2), pp. 251-279. sino retomar las ideas presentes en la mentalidad y el pensamiento judío y grecolatino ${ }^{34}$. Por ello, autores como Ambrosio, Jerónimo o Juan Crisóstomo, cuando realizan sus interpretaciones de los textos bíblicos se olvidan de la primera versión de la Creación presente en la Biblia: "Y creó Dios a los hombres a su imagen; a imagen de Dios los creó; varón y hembra los creó. Y los bendijo Dios diciéndoles: Creced y multiplicaos, llenad la tierra y sometedla" (Génesis 1, 27) para decantarse por la segunda:

32 De extraordinaria utilidad sigue siendo el catálogo de imágenes constatadas por WEIR, A.; JERMAN, J.: Images of Lust... Op. cit., que además aporta mapas de Irlanda, Inglaterra, Norte de la Península y Francia con la distribución geográfica de los distintos motivos que aluden a la lujuria e incluyendo, lógicamente, el de la femme aux serpents.

33 Para el análisis del Pecado Original ver: WENIN, A.: "La serpiente y la mujer o el proceso del Mal según Génesis 2-3". Concilium, Revista Internacional de Teología, 304, 2004, pp. 47-55. MIRANDA, L.R.: “¿Cuál fue el Pecado Original? Traducciones e interpretaciones de Gn 3, 1-24", Circe, no 13 , 2009, pp. 157-171. En este sentido Tertuliano es uno de los autores más radicales, cuando en su De Cultu Feminarum señala: "Mujer, deberías ir siempre de luto, estar cubierta de harapos y entregada a la penitencia, a fin de pagar la falta de haber perdido al género humano...¿¿No sabes que tú eres Eva?.. Tú eres la puerta del diablo, tú eres la que abriste el sello de aquel árbol, tú eres la primera transgresora de la ley divina. Tú eres la que persuadiste a aquél a quien el diablo no pudo atacar; tú destruiste tan fácilmente al hombre, imagen de Dios; por tu merecimiento, esto es, por la muerte, incluso tuvo que morir el Hijo de Dios". TERTULIANO: De Cultu Feminarum o El adorno de las mujeres. Málaga, Servicio de Publicaciones de la Universidad de Málaga, 2001, p. 27. Recogido también por AUBERT, J. M.: La femme. Antiféminisme et Christianisme. París, 1975, p. 191. COLIN-GOGUEL, F.: L'image... Op. cit., p. 159. Ver también: D'ALVERNY, M. TH.: Comment... Op. cit., pp. 105-129. TOLDRÁ I VILARDELL, A.: Asmodeu... Op. cit., pp. 51-62. CASANOVA, E.; LARUMBE, Ma. A.: La serpiente... Op. cit., pp. 337. BETETA MARTÍN, Y.: "Súcubos, hechiceras y monstruos femeninos. Estrategias de desautorización femenina en el exemplum medieval", en SEGURA GRAIÑO, C. (coord.): La Querella de las Mujeres I. Análisis de textos. Madrid, Al-Mudayna, 2010, p. 83.

34 El Génesis no es el único texto del Antiguo Testamento donde se insiste en la asociación entre la mujer y el mal, asociación que ya figura en el Libro de los Jubileos 4,10 o el Eclesiastés 7,8 donde se apunta su atractivo sexual, su carácter lascivo y se hace a las mujeres responsables directas del mal, aunque quizás el más contundente 
“Entonces el Señor Dios formó al hombre del polvo de la tierra, sopló en su nariz un hálito de vida y el hombre se convirtió en un ser viviente. Después el Señor Dios pensó: No es bueno que el hombre esté solo... Entonces el Señor Dios hizo caer al hombre en un letargo y mientras dormía le sacó una costilla y llenó el hueco con carne. Después, de la costilla que había sacado al hombre, el Señor Dios formó una mujer y se la presentó al hombre" (Génesis 2, 7-22).

sea el Testamento de Rubén, texto apócrifo donde la relación entre la mujer, el sexo y la personificación del mal es ya claramente explícita. "Perversas son las mujeres, hijos míos: como no tienen poder o fuerza sobre el hombre, lo engañan con el artificio de su belleza para arrastrarlo hacia ellas... Huid pues, de la fornicación, hijos míos...". Testamento de Rubén, 5, 1-7. Ver: BETETA MARTíN, Y.: “Súcubos...", Op. cit., pp. 78-79. CASANOVA, E.; LARUMBE, Ma.A.: La serpiente... Op. cit., pp. 286-288, donde señalan que en el momento de la aparición del cristianismo la figura del Maligno y la condena sobre el sexo y la mujer están perfectamente asentadas. El análisis sobre la naturaleza de las mujeres en el pensamiento grecolatino arranca de la tradición de los filósofos presocráticos. Al tratar de explicar la naturaleza de la existencia humana, existencia que se manifiesta a través de dos géneros o sexos, el concepto mujer se explicó en relación al concepto hombre. Los griegos, mediante el estudio de la Filosofía Natural, habían descubierto uno de los principios de la creación divina: la sujeción de la mujer. MORAL DE CALATRAVA, P.: La mujer imaginada... Op. cit., pp. 15-39, donde resume que en Grecia existen dos corrientes de pensamiento respecto a la naturaleza de los géneros: una, la mayoritaria en número, que consideraba a las mujeres inferiores a los hombres en aspectos anatómicos, fisiológicos, éticos, legales y sociales, y la otra, encabezada por Sócrates y Platón, que los consideraba iguales en su esencia, si bien reconocían algunas diferencias físicas y psicológicas. Aristóteles por su parte al estudiar la reproducción humana otorga al semen masculino un papel activo y a la mujer un papel pasivo, ya que sólo aporta la materia, lo que le permite afirmar la superioridad masculina respecto a la femenina. Estas teorías o posturas filosóficas fueron traducidas del griego al latín en forma de compilaciones enciclopédicas y formaron el núcleo de la literatura científica romana. Para la configuración del pensamiento misógino en la Antigua Grecia ver: CASANOVA, E.; LARUMBE, Ma.A.: La serpiente... Op. cit., pp. 133226 donde se hace referencia al Mito de Pandora, los monstruos femeninos, los cultos fálicos o los misterios Palingénesicos, además de considerar el pensamiento de Platón, Aristóteles o los estoicos.
De esta manera y aunque los dos estén creados a imagen de Dios, Adán es creado de la nada, pero Eva es creada de Adán con lo que su inferioridad respecto a éste parece clara: ${ }^{35}$ "No consiento que la mujer enseñe ni domine al marido... pues primero fue formado Adán y después Eva" ( I Timoteo 2, 12-14) "Que las mujeres respeten a sus maridos como si se tratase del Señor, pues el marido es cabeza de la mujer"( Efesios 4, 22-23) "Quiero sin embargo que sepáis que la cabeza de todo varón es Cristo, como la cabeza de la mujer es el varón.." (I Corintios 11,3 ) nos dice san Pablo, y san Agustín opina que la serpiente tentó a la mujer "empezando por la parte inferior de aquella humana compañía... juzgando que el varón no era tan crédulo"36. Además está superioridad del varón respecto a la mujer es también una consecuencia del Pecado Original ya que Dios le dice: "Multiplicaré los dolores de tu preñez, parirás a tus hijos con dolor; desearás a tu marido, y él te dominará" $(G n .3,16)$.

La mujer va a ser además la gran perdedora de la transformación del Pecado Original en un pecado sexual ${ }^{37}$. Los textos de los teólogos cristianos

35 A ello se refiere KAPLISCH-ZUBER, C.: "Masculino/ Femenino". En: Diccionario razonado... Op. cit., p. 509. En relación a este hecho es muy significativa la representación del Tapiz de la Creación de la Catedral de Girona en la que Eva surge ya formada del costado de Adán tal como lo hacían Atenea y Dioniso de la cabeza y del muslo de Zeus en las pinturas de las cerámicas griegas de los siglos VI y V a.C. Sobre el tapiz CASTIÑEIRAS, M.: El tapis de la Creació/ El tapiz de la Creación. Girona, 2011. A las dos versiones del Génesis se refiere también BASCHET, J.: L'iconographie médiévale. París, Gallimard, 2008, pp. 298-341, quien recoge numerosos ejemplos iconográficos de la creación de Eva siguiendo la fórmula ya reseñada del tapiz: aparece en el fol. $6 \mathrm{v}$ del Lib.,Cotton, Claudius B. IV de la British Library de Londres datado en el segundo cuarto del siglo XI; en el fol. 3 del ms. 1632 del Musée Condé de Chantilly de la segunda mitad del siglo XII, en el fol. 1v del ms 2554, Biblia moralizada conservada en Vienne y datada a comienzos del siglo XIII o en el fol. 186 de otra, lat.11560 de la Biblioteca Nacional de París fechada hacia 1235-1245.

36 SAN AGUSTín.: La Ciudad... Op. cit., Libro XIV, Cápitulo XI.

37 LE GOFF, J.; TRUONG, N.: Una historia... Op. cit., p. 49. 
hacen hincapié en la maldad intrínseca del goce sexual y en el desprecio sin paliativos por lo carnal y esta postura precisa de un impulsor, un culpable, un ser proclive a la seducción y al pecado que no podía ser aquel hombre creado a "semejanza de Dios", por lo que la lógica patrística reparó en la "otra", en Eva, es decir en la mujer ${ }^{38}$.

De todas maneras, no podemos olvidar que el contexto que rodea a estas manifestaciones en contra de la mujer se produce en un ámbito preciso, eclesiástico y masculino, en el que las exhortaciones a la castidad y a las prácticas ascéticas son constantes. La mujer se ve como sujeto de la tentación que se debe rechazar y como instrumento del diablo, por eso en los relatos de los santos eremitas muchas tentaciones diabólicas se materializaban a través del deseo carnal personificado en figuras femeninas convirtiendo en un topos a la mujer tentadora y así Mujer, sexo y Satán se revelan continuamente en una mezcolanza promiscua, en el sentido más literal de la expresión, para probar la fe de los santos padres ${ }^{39}$. Este es el contexto en el que se gestan las numerosas metáforas cargadas

38 BORNAY, E.: Las hijas de Lilith. Madrid, Ensayos Arte Cátedra, 2004, pp. 32-33, donde también señala que es en el seno de la iglesia cristiana y bajo la enseñanza patrística cuando se afirma el concepto de que el sexo era el Pecado por antonomasia. Ya ha sido señalado además que en el pasaje del Gn 3,16 uno de los castigos que Dios impone a Eva es precisamente "desear a tu marido", dejando bastante claro que a partir de ese momento es la mujer, a través de su deseo, la que incita al hombre. La mayor parte de la carga misógina de estos escritos está vinculada al pecado y al sexo y autores como Juan Crisóstomo lo expresan claramente al señalar "... en las invectivas que leemos contra las mujeres, la palabra hembra indica el placer de la carne". CASANOVA, E.; LARUMBE, Ma.A.: La serpiente... Op. cit., p. 337. Para un estado de la cuestión sobre este tema incluyendo una amplia bibliografía: PEDREGAL, A.: "La Historia de las Mujeres y el Cristianismo primitivo. Apuntes para un balance historiográfico", en: La Historia de las Mujeres: Una revisión historiográfica. Secretaría de Publicaciones e Intercambio Editorial de la Universidad de Valladolid, 2004, pp. 201-228.

39 Para el topos de la mujer tentadora ver: CASANOVA, E.; LARUMBE, Ma.A.: La serpiente...Op. cit., pp. 334-338. PILOSU, M.: La donna... Op. cit., pp. 30-41. BETETA MARTíN, Y.: “Súcubos... Op. cit., p. 84. de significación negativa que ligan a las mujeres con la tentación, el pecado, el mal y las fuerzas diabólicas ${ }^{40}$.

La abnegación y la renuncia al cuerpo son una constante en el monaquismo ${ }^{41}$ y así, cuando San Benito promulga la regla benedictina establece preceptos como "Negarse a sí mismo para seguir a Cristo", "Castigar el cuerpo", "No abrazarse a los deleites" o "No satisfacer los deseos de la carne" ${ }^{42}$, preceptos vinculados a la renuncia al placer y a la lucha contra las tentaciones, puesto que él mismo fue tentado por el diablo a través de la figura de una hermosa mujer, tentación que consiguió ahuyentar mortificando su cuerpo al lanzarse desnudo sobre un matorral de zarzas y ortigas del que salió con el cuerpo completamente llagado ${ }^{43}$.

40 Del VAl Valdivieso, Mạ. I.: "El Mal, el Demonio, la Mujer (en la Castilla Bajomedieval)", en: DEL VAL VALDIVIESO, Ma. I.; / DE LA ROSA, C./ DUEÑAS, M. J. (coord.): Vivir siendo mujer a través de la Historia.. Universidad de Valladolid, 2005, pp. 13-40. También TOLDRÁ I VILARDELL, A.: Asmodeu... Op. cit., pp. 29-62.

41 Tanto las reglas monásticas, como los tratados morales o los opúsculos ascéticos constituyen en su totalidad un enorme tratado sobre los vicios o pecados, ya que para los monjes son obstáculos que deben superar con el objetivo de conseguir el camino de la perfección. Por ello están continuamente librando una doble batalla: contra $s$ mismos y también contra el mundo al que deben dar la espalda. CASAGRANDE, C.; VECCHIO, S.: Histoire des... Op. cit., p. 12.

42 "Abnegáre semetípsum sibi, ut sequátur Cristum", " Corpus castigáre", "Delícias non amplécti", "Desidéria carnis non effícere", Preceptos 10, 11,12 y 59 del Capítulo IV "Quae sunt instruménta bonórum óperum". SAN BENITO.: Su vida y su regla. Madrid, B.A.C., 1968 , pp. $368-383$.

43 Caput II: De tentaione carnis superata. SAN GREGORIO MAGNO. Libro II de los Diálogos. Vida y milagros del Venerable Benito fundador y abad del Monaserio de "Arcis" de la provincia de Campania. Madrid, B.A.C., 1968. pp. 179-181. Los conocidos como Diálogos, cuyo título original es De vita et miraculis Patrum Italicorum et de aeternitate animarum atribuido a san Gregorio, es uno de los textos más populares de la época medieval, presente en todas las bibliotecas y del que se conservan traducciones en griego, anglosajón, francés, italiano, castellano, catalán o árabe. Un capitel de la Madelaine de Vezelay, fechado en el siglo XII, ilustra este episodio a través 
La relajación en la observancia de la regla benedictina durante los siglos altomedievales propició la activación de la reforma monástica que a partir del siglo IX y sobre todo en los siglos X y XI representa un fenómeno político y religioso de primer orden. Entre sus propósitos, y a pesar de la resistencia, destaca la intención de inculcar en la sociedad medieval su visión teocrática del mundo y su ideal ascético que, como ya se ha visto, exalta la virginidad y la castidad. A lo largo del siglo IX la regla de San Benito se va imponiendo poco a poco gracias a la reforma impulsada por Benito de Aniano y a la acción administrativa realizada por el rey Luis el Piadoso $^{44}$. El mejor ejemplo de este monaquismo triunfante es Cluny,

de un horripilante demonio de pelo llameante que lleva de la mano a una "mujer en cabellos" con la que pretende tentar al santo. El tema se reitera en otro capitel de la iglesia abacial de Fleury (hoy Saint-Benoît-sur-Loire) datado entre 1067 y 1108, donde se representa todo el episodio narrado por San Gregorio: la llegada del demonio con la mujer y a San Benito revolcándose en las ortigas. FRUGONI, C.: "L'iconographie de la femme au cours des Xe-Xlle siécles", Cahiers de Civilisation Médiéval, no 20, 1977, p. 183 y Fig. 13 para el capitel de Vezelay. También en PILOSU, M. La Donna... Op. cit., p. 31. COLIN-GOGUEL, F.: L'image... Op. cit., nota 11, p. 88. Pero San Benito no es el único, ni el primero. Todos conocemos otros episodios hagiográficos en los que los santos eremitas son tentados por el deseo carnal, por la lujuria, representada a través de figuras femeninas, siendo uno de los más conocidos el de San Antonio. NUET BLANCH, M.: "San Antonio tentado por la lujuria. Dos formas de representación en la pintura de los siglos XIV y XV “, Locus Amoenus, 2, 1996, pp. 111-124.

44 Benito de Aniano ingresa como monje en el monasterio borgoñón de Saint-Seine y claramente preocupado por el debilitamiento de la disciplina monástica va a intentar llevar a la práctica sus ideales ascéticos y una vivencia literal de la regla de San Benito de Nursia. La difusión de su reforma se verá impulsada en los Sínodos de los años 816 y 817, siendo el diez de Julio de este último año cuando se promulga en los Capitulare Monasticum. A partir de ese momento el rey Luis el Piadoso impone su observancia en los monasterios del reino. DONNAT, D. L.: "Les coutumes monastiques autor de I'an Mil ", dans: Religion et Culture autor de l'an Mil. Royaume capétien et Lotharingie. París, Picard, 1990, pp. 17-18. NEISKE, F.: "Réforme clunisienne et réforme de I'Eglise au temps de l'abbé Hugues de Cluny", en: La reforma gregoriana y su proyección en la Cristiandad Occidental. Siglos XI-XII. XXXII Semana de Estudios Medievales (Estella, 2005), Pamplona, Gobierno de Navarra, 2006, pp. 335-359. fundado en el año 910 por el Duque de Aquitania, y que irá extendiendo su influencia principalmente por este territorio y por Borgoña hasta que los monasterios dependientes de Cluny jalonen una parte importante del Occidente europeo. Pero esta reforma monástica va a tener también otro foco importante más al Norte, foco en el que la abadía de Fleury, hoy SaintBenoît-sur-Loire, se convierte en centro propulsor irradiando su influencia hacia, el Norte de Francia, Lotaringia y los territorios del Imperio ${ }^{45}$. En esta zona, y a diferencia de lo que ocurre en los territorios incluidos en el radio de acción directa de Cluny, algunos obispos van a jugar un papel primordial en su implantación y difusión. Dicho fenómeno se ha explicado, entre otras razones, por la cercanía existente entre las escuelas episcopales y monásticas y por la estrecha relación entre las villas y los grandes monasterios. Uno de sus máximos impulsores fue Adalbero I de Metz quien puso al frente de la abadía de Gorze a Jean, duodécimo abad en el año 933, quien estaba convencido de que la causa fundamental del abandono de la observancia benedictina era el dominio aristocrático de los señores laicos sobre las abadías, lo que les privaba de una gran parte de sus recursos y de la guía espiritual necesaria para preservar sus reglas y preceptos ${ }^{46}$. Abades y también muchos obispos contribuyeron a la reforma

45 D. L. Donnat, que ha analizado las costumbres monásticas, señala que se puede establecer una zona geográfica activa desde Fleury hacia Fulda y Ratisbona, Tréves y Saint-Gall y en la que Lotaringia queda situada en el centro de dicha área de influencia. Apunta que para esa zona sería preferible hablar de "zona franca" para diferenciarla de la "zona aquitana" donde las costumbres monásticas son claramente de tipo cluniacense. Una de las diferencias estriba en el hecho de que esta "zona franca" presenta unas tendencias más conservadoras hacia las costumbres monásticas anteriores a la reforma propugnada por Benito de Aniano y que podrían ser consideradas "modernas" por unas abadías acostumbradas a los hábitos de los monasterios de la zona imperial. DONNAT, D. L.: "Les coutumes monastiques... Op. cit., pp. 17-24.

46 BARONE, G.: "Jean de Gorze. Moine de la réforme et saint original”, dans: Religion et Culture autor de I'an Mil. Royaume capétien et Lotharingie. París, Picard, 1990, pp. 3138. Adalbero I de Metz impulsa la renovación del monasterio de Gorze convirtiéndolo 
de los monasterios, al restablecimiento de la regla, a la renovación de la vida litúrgica y a la reconstrucción de las bibliotecas ${ }^{47}$. Resaltamos esta variante de la reforma monástica porque esta zona geográfica, cuya historia oscila entre el dominio capeto y otoniano, es de donde proceden algunas de las referencias iconográficas y de las fuentes escritas más significativas en relación a la imagen que se está analizando.

en un centro intelectual de primer orden. Desde aquí la reforma monástica se extenderá a otros centros importantes como Metz, Toul o Verdun. PARISSE, M.: L 'abbaye de Gorze dans le contexte politique et religieux lorrain à l'époque de Jean de Vandières (900-974)", dans: MICHEL PARISSE, M.; GERHARD OEXLE, O.(ed.): L'abbaye de Gorze au X siécle.. Nancy, Collection Lorraine, 1993, pp. 51-90. Durante el siglo XI otros impulsores importantes de la reforma monástica son los abades Richard de SaintVanne, Poppon de Stavelot, Léduin de Saint-Vaast de Arras, el obispo Gerard de Cambrai o el conde Baudoin IV de Flandes. Para la irradiación de la reforma desde el monasterio de Fleury, hoy Saint-Benoît-sur-Loire, hacia Lotaringia y otros territorios del Norte ver: MOSTERT, M.: "La bibliothèque de Fleury-sur-Loire", dans: Religion et Culture autor de l'an Mil. Royaume capétien et Lotharingie. París, Picard, 1990, pp. 120123 donde destaca la importancia del apogeo cultural de Fleury entre los años 800 y 1150.

47 RICHÉ, P.: "Éducation el cultura autor de I'an Mil. La place de la Lotharingia", dans: Religion et Culture autor de I'an Mil. Royaume capétien et Lotharingie. París, Picard, 1990, pp. 279-283. Para la originalidad de la reforma de Gorze y sus diferencias con Cluny el estudio de referencia es el de HALLINGER, K.: Gorze-Kluny. Studien zu den monastischen Lebensformen und Genensätzen in Hochmittelater. Studia anselmiana, 22-23, 24-25, Roma, 1950-1951, aunque para los autores que se han ocupado de este tema sus argumentaciones resultan un poco forzadas. De hecho, hoy día, los estudios críticos con su tesis profundizan en la influencia de la reforma sobre aspectos específicos como la vida monástica, la gestión económica, la producción de manuscritos o la gestión de las bibliotecas en lugar de intentar establecer una disciplina monástica global diferente a Cluny. VANDERPUTTEN, S.: "Identité collective et mémoire des réformes "richardiennes" dans I'historiographie bénedictine en Basse-Lotharingie et au Nord-Est de la France (XIe-XIle siécles)", Le Moyen Age 2/2011, Tome CXVII, pp. 259-289. BARONE, G.: "Gorze e Cluny a Roma", dans: GOUGUENHEIM, S. (ed.): Retour aux sources. Textes, études et documents k'histoire médiévale offerts à Michel Parisse. París, 2004, pp. 583-590. De todas formas y como ya se ha señalado, la renovación de
La orden benedictina siempre ha insistido en el peligro de la tentación femenina y la reforma monástica, que va a imponer la observancia estricta de sus preceptos, va a intentar extrapolar este sistema moral a los laicos intentando guiar y reconducir su comportamiento. Odón de Cluny recomienda a los laicos llevar una vida piadosa siguiendo el ejemplo de un caballero cristiano que, entre otros méritos, se resiste a los vicios.

Por ello los sermones y escritos de estos monjes reformadores describían con una claridad elocuente el proceder pecaminoso y los castigos y tormentos del infierno intentando estremecer la fantasía y el alma de los hombres ${ }^{48}$. La transmutación iconográfica y semántica de la imagen que nos ocupa coincide con la reforma monástica que se va imponiendo por Occidente durante los siglos X y XI y la difusión de la femme aux serpents, cuya representación aparece ya fijada en el último tercio del siglo $\mathrm{XI}$, se corresponde a su vez con el momento en que la influencia de esta reforma monástica se deja sentir sobre la reforma de la Iglesia impulsada desde el papado en la segunda mitad del siglo XI y que todos conocemos como Reforma Gregoriana ${ }^{49}$.

la vida intelectual y espiritual en centros como Metz, Verdún o Toul está vinculada a papel desempeñado también por sus obispos entre finales del siglo $X$ y comienzos del siglo XI. Para esta cuestión y las vinculaciones políticas y familiares entre Lotaringia, los reyes francos y los emperadores otones ver: PARISSE, M.: "Les hommes et le pouvoir dans la Lorraine de l'an Mil", dans: Religion et Culture autor de l'an Mil. Royaume capétien et Lotharingie. París, Picard, 1990, pp. 259-266.

48 NEISKE, F.: "Réforme clunisienne... Op. cit., pp- 353-354 para la consideración que muestra Cluny hacia los laicos. WEISBACH, W.: Reforma religiosa... Op. cit., pp. 25-26 y 87. A la insistencia de Cluny en los peligros de la seducción femenina y al papel que jugaron en la consideración negativa de las mujeres durante los siglos medievales se refiere también PILOSU, M.: La Donna... Op. cit., pp. 38 y 55.

49 Para la posible relación entre la reforma eclesiástica y el arte de aquel momento ver: TOUBERT, H.: Un art dirigé: réforme grégorienne et iconographie. París, Editions du Cerf, 1990. El tema ha sido retomado recientemente en diversos estudios por 
Ya se ha señalado al inicio de estas páginas que para comprender por qué una imagen de tradición clásica como Tellus, la Tierra-Madre, se utiliza como referencia visual para crear otra con un trasfondo semántico radicalmente distinto, no se pueden obviar aspectos tan significativos como los aquí tratados. Todos entran en juego por estar plenamente vigentes en la mentalidad de aquel momento y son los que propician el éxito de una iconografía que aúna femineidad, sexo y pecado, es decir que lo reúne todo para convertirse en encarnación rotunda y singular del vicio.

Gea, esposa de Urano, era considerada en Grecia como una gran deidad primitiva. Símbolo de la tierra y su fecundidad era la madre por excelencia, ya que se le considera progenitora de casi todos los monstruos y seres gigantescos de la mitología. Hesíodo en su Teogonía comienza su historia del Universo diciendo: "Ante todo existió el Caos. Después aparecieron Gea de ancho pecho, morada perenne y segura de los seres vivos..". En la cultura romana fue denominada Tellus, Tierra-Madre, se afirmó como divinidad ectónica y su culto se difundió bajo la influencia de las doctrinas estoicas. Su representación se fija a través de la imagen de una mujer joven parcialmente desnuda, sentada o recostada en medio de un paisaje con plantas o árboles y rodeada de animales entre los que puede figurar la serpiente. Otros elementos presentes suelen ser el cuerno de la abundancia y los niños, karpoi, que en ocasiones amamanta o lleva en los brazos o el regazo. Su representación junto a Océanos procede de los sarcófagos romanos en los que como símbolo de renacimiento se asocia al otro principio generador de vida, el agua ${ }^{50}$.

TRIVELLONE, A.: L'hérétique imaginé: hétérodoxie et iconographie dans l'Occident médiéval. Brepols, Turnhout, 2009 y de la misma autora "L'arte e la Riforma ecclesiastica tra XI e XII secolo", dans: ECO, U. (dir.): Medioevo, Cattedrali, Cavalieri, Cittá, Milán, Encycomedia, 2011, pp. 605-611.

50 LECLERCQ-KADANER, J.: De la Terre... Op. cit., pp. 37-38. Entre las referencias destacan las representaciones de Gea en la iconografía griega, fundamentalmente en la cerámica, en las que aparece surgiendo de la tierra. En ellas la parte superior del
La iconografía de la Tierra-Madre asociada a Océanos se recupera en el arte carolingio pero lógicamente con una lectura diferente. Es frecuente su representación en las crucifixiones de marfil u otras teofanías con sentido cósmico en las que la fecundidad telúrica se interpreta ahora como la abundancia y la felicidad de la Nueva Tierra renovada por Cristo transformándose en una maternidad espiritual. No es extraño que en estas cubiertas ebúrneas las teofanías aparezcan rodeadas por alegorías de origen clásico: el sol y la luna en la zona superior y la tierra y el mar en la inferior, ya que hay textos de la época que hablan de la purificación de la tierra, el océano, los astros y los hombres a través del sacrificio de Cristo en la cruz $^{51}$. Su significación sigue remitiendo a la personificación de un elemento de la naturaleza pero inserta ahora en un ciclo sacro y en un contexto pascual ${ }^{52}$.

cuerpo de Gea es claramente visible mientras que la inferior forma parte del sustrato terrestre, tal como se aprecia también en los relieves del Altar de Pérgamo. En este sentido ilustraciones como la personificación de la Tierra que aparece en el Apocalipsis de Tréveris, siglo IX, parecen derivar de estas representaciones. Mayor vinculación con la femme-aux-serpents presentan las imágenes romanas de Tellus, destacando las del relieve del Ara Pacis, los sarcófagos en los que figura acompañada de Océanos, como el sarcófago Mattei, o las ilustraciones de las gemas antiguas. En este caso los karpoi que la acompañan son dioses infantes de los frutos de la tierra.

51 En el Himno Pange Lingua de Venantius Fortunatus se señala la purificación de "terra, pontus, astra, mundus". Ver: WIRTH, K. A.: "Erde", dans: Reallexicon zur deutschen Kunstgeschichte. Tom. V pp. 997-1103. Stuttgart, 1967, p. 1056 para esa referencia concreta (de ahora en adelante Reallexicon). Citado también en LECLERCQ-KADANER, J. De la Terre... Op. cit., p. 38, nota 18. *Agradecemos a Mikel Basabe la ayuda que nos ha prestado en la traducción y comprensión de los textos en alemán de las obras de K.A. Wirth y A. Goldschmidt.

52 Ibidem, p.38. A ello se refieren también: RODRÍGUEZ LÓPEZ, Mạ. I.: “Pervivencias iconográficas del mundo clásico en los códices prerrománicos: la personificación del mar", Cuadernos de Arte e Iconografía, no 11, 1993, pp. 218-224. NODAR FERNÁNDEZ, V.: "De la Tierra Madre a la Lujuria: a propósito de un capitel de la girola de la Catedral de Santiago", Semata, vol. 14, 2002, pp. 338-341, donde apunta que la utilización de motivos iconográficos de la Antigüedad clásica como referencia era legitimado por su 
Uno de los ejemplos más significativos es la cubierta de marfil del $\mathrm{Clm}$ 4452 conservado en la Bayerische Staatsbibliothek de Munich. Su datación oscila entre el 840 y el 870 y está vinculado a la Escuela de Palacio de Carlos el Calvo. El relieve ilustra la Crucifixión, la Resurrección y una alusión al Juicio Final. Los temas sacros centrales aparecen rodeados por motivos de pervivencia clásica: las personificaciones de Helios y Selene sobre cuadrigas en la parte superior y de la Roma pagana, Océanos y la TierraMadre en la parte inferior. Esta última se representa con el cuerno de la abundancia y parcialmente desnuda, con los senos al descubierto y dando de mamar a una serpiente. Su iconografía se ha asociado al pasaje del Génesis 3, 14 y por lo tanto al Pecado Original ${ }^{53}$. (Fig. 2).

consideración de imágenes apropiadas y convenientes. Además se utilizaban como instrumentos de prestigio figurativo con el propósito de magnificar las obras y poner de manifiesto el bagaje intelectual del entorno cultural y artístico en que se habían producido. Ahora bien, una vez asimiladas a las nuevas creencias cristianas, su significado podía cambiar de manera sustancial para ser utilizadas en clave moralizante. Para la pervivencia de motivos iconográficos de la Antigüedad en la Edad Media ver los estudios ya clásicos de OAKESHOTT, W.: Classical Inspiration in Medieval Art. New York, Frederick A. Praeger, 1960. PANOFSKY, E.: Renacimiento y renacimientos en el arte occidental. Madrid, Alianza, 1975. SETTIS, S.: "Continuitá, distanza, conoscenza. Tre usi dell'antico", en Memoria dell'antico nell'arte italiana, III, Turín, 1986. SEZNEC, J.: Los dioses de la Antigüedad en la Edad Media y el Renacimiento. Madrid, Taurus, 1983.

53 GOLDSCHMIDT, A.: Die Elfenbeinskulpturen aus der Zeit der Karolingischen und sächsischen Kaiser, VIII-XI Jahrhundert. Berlín, Ed. Deustscher Verlag, 1969. Tom.I, p. 25. llus. 41, uno de los catálogos más completos en relación a los marfiles prerrománicos centroeuropeos. Goldschmidt lo data hacia el 870 , momento más esplendoroso de esta escuela palatina, pero en las referencias a esta obra incluidas en el catálogo del Victoria and Albert Museum su cronología se adelanta hasta el 840. htpp://collections.vam.ac.uk/item/072543/the-crucifixion-panel-unknown/ De todas maneras el relieve se vincula a las obras del grupo Liuthard, cuya primera referencia aparece en el Salterio de Carlos el Calvo: "Hic calamus facto Liuthardo fine quievit" (fol. 172v), quien también firma junto a su hermano Beringar el Codex Aureus de SaintEmmeram de Ratisbona (Munich, Bayerische Staatsbibliothek, Clm 14000) en el año 870. La cronología del Salterio oscila entre el 842 y el 869 . Ver: Trésors carolingiens.
Durante el siglo IX la iconografía de la Tierra-Madre en el arte carolingio presenta diferentes variantes. Es habitual que aparezca con el cuerno de la abundancia o con ramas floridas y otros dos de los elementos más constantes son los niños y la serpiente. Estos dos últimos elementos son, sin duda alguna, bastante más significativos de cara a la transmutación semántica de la imagen. En el caso de la serpiente su asociación a la TierraMadre viene determinada por su carácter ectónico, por su cualidad de animal ligado a la tierra ${ }^{54}$ y por ser símbolo de la perenne renovación de la naturaleza, pero además, y ya desde la Antigüedad, la serpiente es un animal vinculado a la mujer, la fertilidad y el sexo ${ }^{55}$. Todos sabemos que la

Livres manuscrits de Charlemagne á Charles le Chauve. Bibliothéque Nationale de France, 2007, p.108. A la cubierta de este códice se refieren también: LECLERCQKADANER, J.: De la Terre... Op. cit., p. 39. Fig.1. RODRÍGUEZ LÓPEZ, Mạ. I.: Pervivencias... Op. cit., p.3.Fig. 1 quien señala que se trata de una obra maestra de la eboraria, con un virtuosismo técnico incomparable y que está enmarcada por una magnífica orla de oro y esmaltes e incrustación de piedras preciosas que fue realizada en tiempos de Enrique II (1024-1026). NODAR FERNÁNDEZ, V.: De la Tierra-Madre... Op. cit., p. 337. Fig.3, quien data la cubierta hacia el 820-830. WEIR, A.; JERMAN, J.: Images of Lust... Op. cit., p. 67. Para WIRTH, K. A.: Reallexicon... Op. cit., p. 1057 esta iconografía de la TierraMadre es una interpretación literal del pasaje Gn, 3, 14 en el que Dios condena a la serpiente a alimentarse constantemente de la tierra.

54 "El vocablo anguis designa genéricamente toda clase de serpientes, que pueden plegarse y retorcerse; y se le dice anguis por su avanzar "anguloso" y nunca derecho. Entre los paganos siempre eran consideradas como genios de un lugar. .. La serpiente recibe su nombre de que se desliza (serpere) por lugares intrincados, nunca por caminos abiertos; y repta apoyándose en sus diminutas escamas... reptan con su vientre y su pecho.... De ellas existen tantos venenos cuantas clases de serpientes hay; tantas dañinas cuantas son las especies que existen; $y$ tantos dolores cuantos son sus colores.... En las cualidades naturales comunes a nosotros y a los animales irracionales, la serpiente nos aventaja por una cierta vivacidad de sus sentidos. Por ello leemos en el Génesis $(3,1)$ "La serpiente era la más sabia entre todos los animales de la tierra". SAN ISIDORO.: Etimologías XII, 4 Sobre las serpientes. Op. cit. También en: CASANOVA, E. LARUMBE, Ma. A.: La serpiente vencida... Op. cit. pp. 267.

55 CASANOVA, E.; LARUMBE, Ma..A.: La serpiente vencida... Op. cit., pp. 25-31. DIÉZ PLATAS, F.: "Imaginando el agua: reflexiones sobre el significado iconográfico del 
mentalidad cristiana convierte a la serpiente en una criatura diabólica y maléfica. El papel que desempeña en el Pecado Original incitando a Eva a comer del árbol prohibido hace de ella un animal maldito y su condena la llevará a arrastrarse sobre su vientre y comer polvo todos los días de su vida $(G n .3,14)$. La maldición divina la convierte en el peor animal de la Creación y en encarnación del propio demonio. Ya he señalado líneas atrás que esta es una de las lecturas que se realiza de la representación de la Tierra-Madre en la cubierta citada. De hecho el arte carolingio es el responsable de haber difundido la presencia de la serpiente enroscada en la parte baja de la cruz como símbolo del maligno. Se contrapone así redención y pecado y se pone de manifiesto la victoria de Cristo sobre la muerte cumpliendo la promesa de maldición del Génesis ${ }^{56}$.

motivo de la serpiente en ciertas escenas de la cerámica griega arcaica", en: Fronteras e identidad en el mundo griego antiguo. Santiago, 2001, p. 284. Para la iconografía de la serpiente en la cultura griega ver también: RODRÍGUEZ PÉREZ, D.: "El combate contra la serpiente: el triunfo de la tierra velado bajo la aparente muerte del oficio", De Arte, № 5, 2006, pp. 5-14. De la misma autora: Serpientes, dioses y héroes: el combate contra el monstruo en el arte y la literatura griega antigua. Universidad de León, 2008. "La serpiente como símbolo en el mundo griego: Escenas del más acá", en: SÁNCHEZ MANZANO, A. (coord.): Sabiduría simbólica y enigmática en la literatura grecolatina. 2011, pp. 97-116. "La serpiente en la iconografía vascular griega del S.VI a.C", en: Ianua Classicorum: temas y formas del mundo clásico (2Vols.), 2015, pp. 723-730. Para la pervivencia de la tradición clásica en las serpientes de la Edad Media ver: GONZÁLEZ ZYMILA, H.: "Tradición clásica en la serpiente del Medievo", Revista de Arqueología, № 260, 2002, pp. 46-53. NODAR FERNÁNDEZ, V.: De la Tierra-Madre... Op. cit., p. 341. LECLERCQ-KADANER, J.: De la Terre... Op. cit., p. 39 refiere por su parte la existencia de divinidades primordiales greco-orientales, cretenses o sirias, que portan serpientes en sus brazos.

56 Gn 3, 15. WENIN, A.: La serpiente y la mujer... Op. cit., pp. 47-55. CASANOVA, E.; LARUMBE, Ma. A.: La serpiente vencida... Op. cit., pp. 288. NODAR FERNÁNDEZ, V.: De la Tierra-Madre... Op. cit., p. 343. La presencia de la serpiente enroscada en la parte inferior de la cruz se introduce en el arte cristiano a partir del 820. YARZA LUACES, J.: "Iconografía de la Crucifixión en la miniatura española. Siglos X al XII", Archivo Español de Arte 47:185, 1974, pp. 20-30.

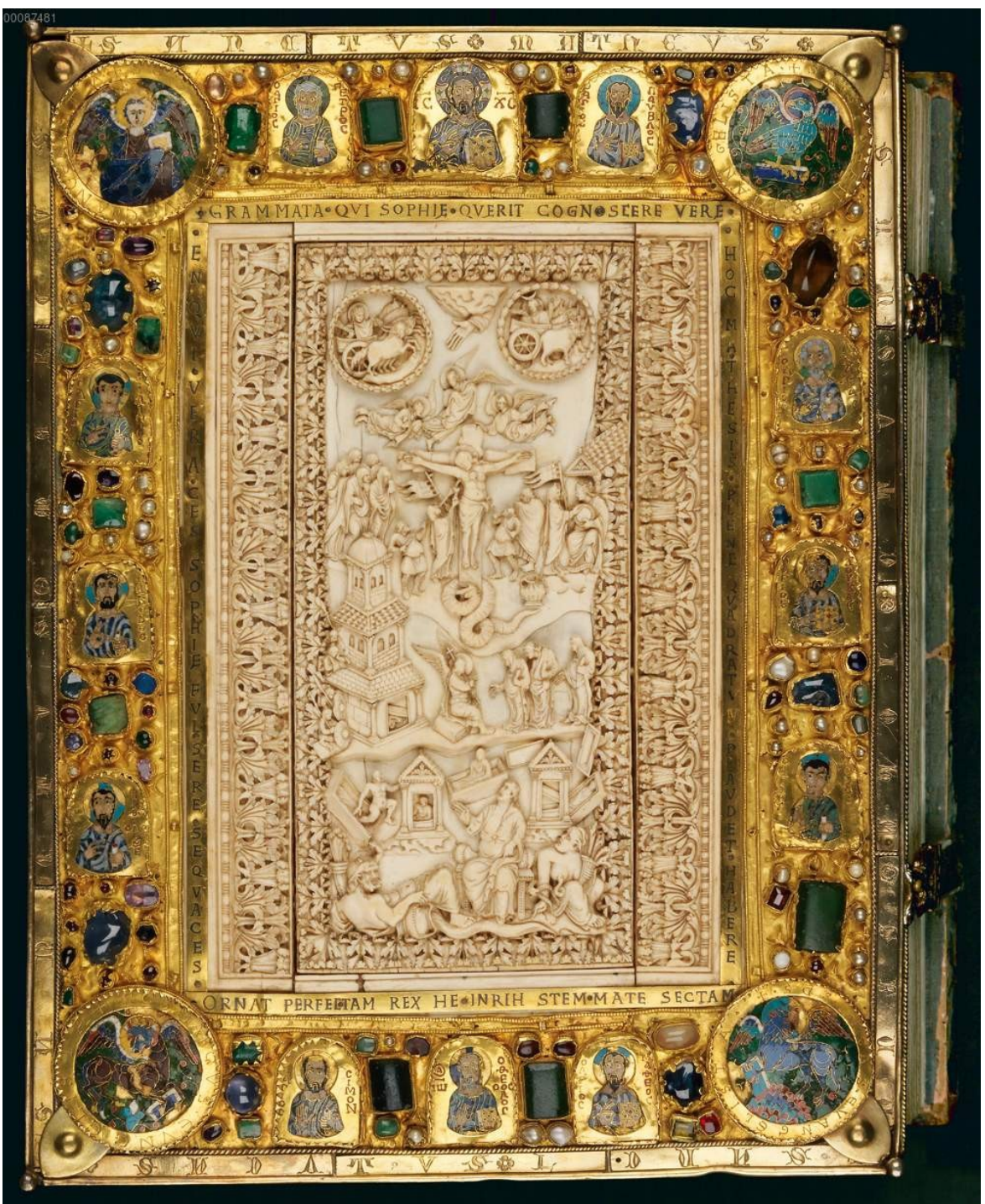

Fig. 2. Cubierta de marfil, Clm 4452 (Libro de Pericopas), München, Bayerische Staatsbibliotek. htpp://daten.digitale-sammlungen.de/ db/0008/bs00087481/images (12/12/2016) 
La presencia de la serpiente es una constante en muchas de las fuentes visuales recopiladas para este estudio, aunque en la mayor parte de las ocasiones aparece enroscada en el brazo de la Tierra-Madre ${ }^{57}$ o situada junto a ella. Su presencia obedece claramente a un modelo de referencia antiguo, pero no podemos perder de vista la significación de este animal en el pensamiento medieval, significación que además se ve reforzada por el hecho de que para la mentalidad cristiana la Tierra, lo terrenal, es el lugar del pecado: "Haced morir, pues, lo terrenal en vosotros: fornicación, impureza, pasiones desordenadas, malos deseos y avaricia, que es idolatría" (Colosenses, 3,5) situando en primer lugar los pecados de la carne.

Parece claro que la consideración de la serpiente como animal diabólico y asociado además a la Tierra es uno de los factores que parece estar detrás del cambio semántico de este motivo iconográfico. Todos sabemos que la serpiente es uno de los animales preferidos para atormentar a los pecadores. Su presencia es casi imprescindible en las escenas que ilustran los castigos infernales y autores como J. Adhémar ya señalaron que la transformación de este motivo se produjo en el momento en el que los escultores interpretaron la imagen simbólica de la Tierra-Madre amamantando una serpiente como una escena de suplicio ${ }^{58}$. Ahora bien,

57 Para LECLERCQ-KADANER, J.: De la Terre... Op. cit., p. 39 el atributo de la serpiente enroscada en el brazo de la Tierra-Madre procedería de una contaminación entre las figuras de Tethys y Terra, las dos asociadas a Océano. En la iconografía antigua es Tethys la que lleva la serpiente enroscada en el brazo, pero esta divinidad no fue objeto de una alegorización cristiana y la iconografía medieval asoció la serpiente a las representaciones de la Tierra-Madre, lo cual no suponía ninguna inconveniencia dado su carácter de símbolo ectónico por excelencia.

58 ADHÉMAR, J.: Influences... Op. cit., p. 198. Esta reflexión de Adhémar es recogida también por NODAR FERNÁNDEZ, V.: De la Tierra-Madre... Op. cit., p. 341, donde señala que en Santiago de Compostela dicha transformación no parece un error de interpretación, sino una utilización consciente de este modelo clásico pero adaptado a un nuevo contenido moralizante. esta interpretación por sí sola no explica su asimilación al pecado de la lujuria y su castigo, máxime si consideramos que los escultores o mazoneros no solían ser los responsables de la mutación semántica de los motivos iconográficos. Además, las representaciones de la Tierra-Madre amamantando serpientes son relativamente escasas en relación a otras fórmulas iconográficas de mayor fortuna, destacando las que muestran a la Tierra-Madre con la serpiente enroscada en un brazo y acompañada de dos pequeños personajes. En la monografía de A. Goldschmidt y los estudios de J. P. Caillet se puede ver un repertorio bastante completo de las mismas, obras, en su mayoría, vinculadas a la denominada Segunda Escuela de Metz: Lat. 9383 de la Biblioteca Nacional de París; Nr 25067, Nr 25167 y Nr 26667 del Victoria and Albert Museum de Londres, una cubierta conservada en la Colección Martin le Roy de París y otra, hoy desaparecida, que se conservaba en el Museo Arqueológico de Tournai ${ }^{59}$ (Fig. 3).

59 Metz, villa imperial, es un centro político, religioso y artístico de primer orden durante la primera mitad del siglo IX. Bajo la tutela de Drogon, obispo de la diócesis desde el 821 e hijo bastardo de Carlomagno se iluminaron manuscritos magníficos como su Sacramentario (BNF latin 9428) y el scriptorium se especializó en la realización de obras en marfil, fundamentalmente tapas de códices entre las que destacan las del propio Sacramentario citado o las de su Evangeliario (BNF latin 9388 y 9393 para las cubiertas). Ver: TRÉSORS... Op. cit., pp.189-205. Los relieves citados en el texto están adscritos a la denominada Segunda Escuela de Metz, activa entre el último tercio del S.IX y principios del siglo $X$ y cuyos ecos perduran aproximadamente hasta el año Mil presentando mayores vinculaciones con el foco artístico de Carlos el Calvo que con las obras realizadas en Metz en la primera mitad del siglo. En relación a los relieves de marfil se sabe que su número es elevado, pero se habla de una producción un tanto repetitiva y estereotipada. En el primero de los relieves citado, conocido como Evangeliario de Metz y datado hacia el 875 la Tierra-Madre aparece junto a Océanos y ambos flanquean a una personificación de Roma que porta un estandarte y una esfera del mundo. Todos elevan su mirada hacia la crucifixión de la parte superior del relieve. En este caso los elementos que acompañan a la Tierra-Madre son la serpiente enroscada en un brazo y una cornucopia florida en el otro, brazo sobre el que se apoyan los dos pequeños personajes. GOLDSCHMIDT, A.: Op. cit., Tom.l., pp. 46-47. Ilus.83. TRÉSORS... Op. cit., p. 42 para la imagen y pp. 204-205 para las referencias al reborde de orfebrería con esmalte cloissoné y piedras preciosas y a la inscripción que 
Significativos son también los ejemplos en los que la Tierra-Madre aparece amamantando a los niños o pequeños personajes que le acompañan. Extraordinariamente suntuosa es una de las miniaturas del denominado Sacramentario de Carlos el Calvo en la que vemos a un Cristo en majestad inscrito en una mandorla y flanqueado por ángeles, dos magníficos serafines. En la parte inferior de la composición y elevando la mirada para observar la Teofanía que figura sobre ella, la Tierra-Madre aparece recostada con la parte superior de su cuerpo desnudo y amamantando a dos pequeñas figuras. Ramas floridas de color dorado rodean la escena y crean un tocado sobre su cabeza. La miniatura pertenece al fol.6 del Lat. 1141 de la Biblioteca Nacional de París, datado hacia el 870 y vinculado al taller real ${ }^{60}$ (Fig. 4).

dice: "In cruce restituit Christus, pia victima factus/ Quod mala fraus tulerat serpentis preda ferocis". También CAILLET, J. P.: "Metz et le travail de l'ivoire vers I'an Mil”, dans Religion et Culture autor de I'an Mil. Royaume capétien et Lotharingie. París, Picard, 1990, pp. 315-337, Fig. 2, quien cuestiona que en la denominada Segunda Escuela de Metz, dicha villa imperial sea el único centro productor de estas obras. Con una cronología muy similar los relieves conservados en el Victoria and Albert Museum de Londres que presentan una iconografía de la Tierra-Madre muy parecida, sobre todo el $\mathrm{Nr}$ 25067. En el caso del $\mathrm{Nr} 25167$ los dos pequeños personajes son personas adultas a tenor del rostro barbado que parece presentar uno de ellos y en el $\mathrm{Nr} 26667$ sólo vemos un pequeño personaje tras el brazo que sostiene la cornucopia florida. GOLDSCHMIDT, A.: Op. cit., Tom.l., pp. 47-49 y 66. Ilus. 85, 88 y 132a. Para la llus. 85 ver también WIRTH, K. A.: Reallexicon... Op. cit., p. 1014. CAILLET, J. P.: Metz et le travail... Op. cit., Fig. 12 para el $\mathrm{Nr}$ 25067, cubierta que en su opinión procede de Verdun, p. 316, nota 6 y Fig. 14 para el $\mathrm{Nr}$ 25167. Dicha procedencia también en WILLIAMSON, P.: Medieval Ivory Carvings. Early Christian to Romanesque. London, V\&A Publishing, Victoria and Albert Museum, 2010, pp. 186-189, cat.no. 45 y cat.no. 44 para el $\mathrm{Nr}$ 25167. En el caso del relieve de la colección Martin le Roy, datado en el siglo IX, son constantes la serpiente y la cornucopia florida aunque no aparecen los pequeños personajes y la Tierra-Madre muestra la parte superior del torso desnudo con los senos bien visibles. GOLDSCHMIDT, A.: Op. cit., Tom.I., p. 54. Ilus. 100. Por último el relieve que se conservaba en Tournai muestra una iconografía prácticamente idéntica a los primeros ejemplos citados, sobre todo al Nr 25067. GOLDSCHMIDT, A.: Op. cit., Tom.I., p. 44 y Tom.II., p. 7. CAILLET, J. P. Metz et le travail... Op. cit., Fig. 8.

60 Se trata de un manuscrito incompleto, probablemente encargado por Carlos el Calvo

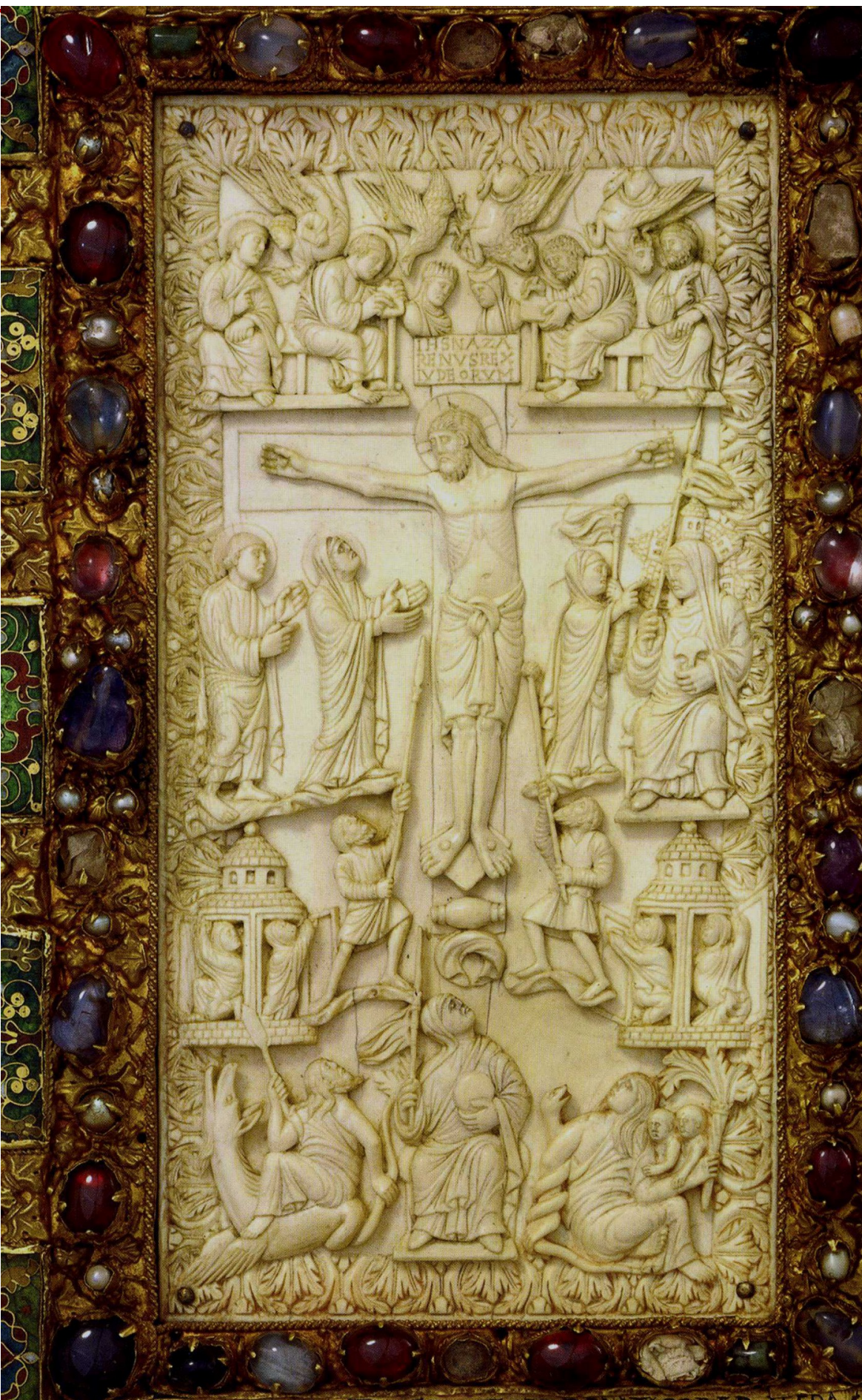




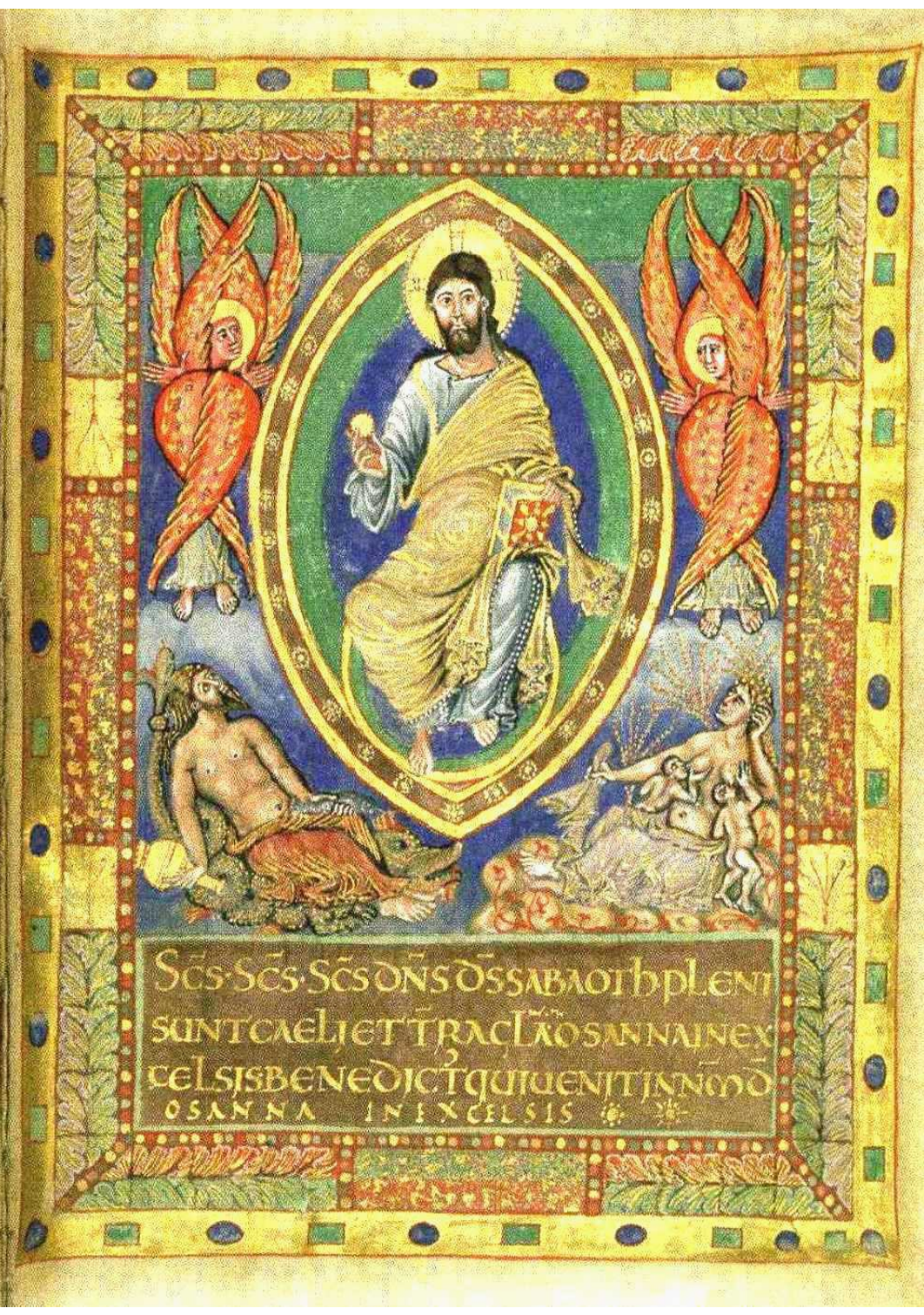

Fig. 4: Sacramentario de Carlos el Calvo, Latin 1141, fol. 6. (C) Bibliothèque national de France
A finales del siglo IX pertenece también la cubierta de marfil del Nr 160 conservada en el Bayerische Nationalmuseum de München en el que la Tierra-Madre aparece con la cornucopia florida y protegiendo con sus brazos a dos pequeñas figuras desnudas a las que amamanta ${ }^{61}$.

Debo resaltar que esta fórmula iconográfica de la Tierra-Madre amamantando parece estar asociada a obras adscritas a la escuela palatina de Carlos el Calvo y relacionadas con el denominado Grupo Liuthard, como es el caso de estas dos últimas representaciones, así como del Clm 4452, ya citado, y donde aparece amamantando a una serpiente. Algo más tardías son las dos representaciones vinculadas al grupo Kleine, grupo que según A. Goldschmidt presenta ciertas influencias del grupo Liuthard. Hacia el año 900 está datado el Cod. 53 de la Stiftsbibliothek de St. Gallen donde debajo de la Maiestas Domini rodeada de ángeles y de los evangelistas con sus símbolos figura la Tierra-Madre con una cornucopia florida y amamantando en este caso a un único niño al que rodea con su brazo. Al siglo $\mathrm{X}$ pertenece la cubierta del $\mathrm{Nr} 509$ conservado en el Darmstadt Grobherzugl Museum en Bélgica donde la Tierra-Madre aparece debajo de la representación del profeta Jesaías y amamantando también a un pequeño personaje ${ }^{62}$.

La identificación de los dos pequeños personajes que suelen acompañar a la Tierra-Madre como Adán y Eva ya fue señalada por J. Leclercq-Kadaner y

61 GOLDSCHMIDT, A.: Op. cit., Tom. I, p. 28. Ilus. 44. WIRTH, K. A.: Reallexicon... Op. cit., p. 1012. Fig. 7. LECLERCQ-KADANER, J.: De la Terre... Op. cit., p. 39. Fig. 2, donde el pie de foto aparece equivocado ya que dicha representación no pertenece al Ms. lat. 9383 y la referencia para la imagen del estudio de Goldschmidt no es la ilus. 83 sino la ilus. 44 .

62 GOLDSCHMIDT, A.: Op. cit., Tom. I, pp. 80-81. Ilus. 163a para la primera imagen donde la inscripción que rodea la composición dice: "HIC RESIDET XPC VIRTUTUM STEMMATE SEPTUS". Ibidem, pp. 79-80. Ilus. 162 para la segunda, donde la imagen de la TierraMadre amamantado se utiliza como contraposición a la visión celestial del profeta Jesaías. 
apuntada por otros autores como A.Weir y J. Jerman. En la misma línea se manifiesta K. A. Wirth cuando refiere que estos pequeños personajes son una reminiscencia de los antiguos karpoi que acompañaban a Tellus y los asimila a Adán y Eva, sobre todo si en la escena aparecen también la serpiente y el árbol. Cuando hay un único personaje puede hacer alusión a Adán, fundamentalmente en las obras otonianas, o a la Veritas como su hijo simbólico ya que su origen está en la tierra, pero esto ya en obras más tardías. Las fórmulas iconográficas de la Tierra-Madre amamantando o acompañada de los dos pequeños personajes irán desapareciendo de las obras centroeuropeas a lo largo del siglo $\mathrm{XI}^{63}$.

Como se ha visto hasta ahora, es la asociación de la Tierra-Madre a los protagonistas del Pecado Original el camino que lleva a su posterior asimilación al castigo de la lujuria. Que la Tierra aparezca acompañada por la serpiente y cobijando o amamantado a Adán y Eva nos recuerda que, aún siendo una Tierra renovada por el sacrificio de Cristo, sigue siendo el

63 Para toda esta cuestión ver: LECLERCQ-KADANER, J.: De la Terre... Op. cit., p. 39. WEIR, A.; JERMAN, J.: Images of Lust... Op. cit., p. 67. WIRTH, K. A.: Reallexicon... Op. cit., p. 1034, quien en relación a la identificación de un único personaje como Adán señala el fol. 34v del ms. 211 de la Biblioteca Nacional de Atenas que contiene las homilías de Juan Crisóstomo, códice datado en el siglo X. En dicha representación la Tierra-Madre aparece semidesnuda, con los senos al descubierto, una rama florida sobre la cabeza y lo que es más singular, reptando o arrastrándose sobre su cuerpo de una forma muy similar a como será representada dos siglos más tarde la Eva de San Lázaro de Autun. Sostiene en su mano una pequeña figurita asimilada a Adán que a su vez sirve de sostén o apoyo a una representación de Cristo. Dicha imagen miniada se ha vinculado con el pasaje evangélico de Lucas 15,8 centrado en la parábola en la que Jesús hace alusión a la oveja descarriada. Ibidem, p. 1024. Fig. 10. Otro de los ejemplos apuntados es el fol 60 del Cod. theol., un evangeliario del siglo X conservado en Kassel donde en la parte inferior de la escena de la Crucifixión una Tierra-Madre, también semidesnuda, sostiene a Adán a la altura de la serpiente que figura en la parte inferior de la cruz mientras éste parece elevar sus brazos hacia Cristo crucificado. Ibidem, p. 1026. Fig. 11. Esta última también es citada por LECLERCQ-KADANER, J.: De la Terre... Op. cit., p. 39. nota 24. lugar del Pecado como dijo San Pablo y así parece ponerlo de manifiesto uno de los relieves más significativos en relación a esta cuestión.

Se trata de una cubierta de marfil realizada hacia el año 1000 para Adalbero II obispo de Metz que se conserva en el Musée de La Cour d'Or de esa localidad ${ }^{64}$. El relieve muestra la escena del Pecado Original en la parte inferior de la cruz, lugar reservado normalmente para la serpiente como símbolo del maligno, con el árbol cobijando a Eva que arrodillada toma la manzana de la boca de la serpiente mientras Adán permanece sentado a su lado pensativo y melancólico. Flanqueando esta pequeña composición figura el Tetramorfos y debajo la representación de Océanos y de la Tierra-Madre semidesnuda, con la serpiente enroscada en un brazo y acompañada de dos pequeñas figuras cobijadas en el otro. (Fig. 5). La representación del Pecado Original debajo de la crucifixión subraya la responsabilidad de sus protagonistas en la muerte y el sacrificio de Cristo. Además, que los protagonistas de ese hecho, Adán, Eva y la serpiente vuelvan a aparecer asociados a la figura de la Tierra-Madre resulta sumamente ilustrativo ${ }^{65}$. Al fin y al cabo el Pecado original es la fuente de todos los pecados posteriores, pecados que además, son ya terrenales.

\section{Pagina siguiente:}

Fig. 5: Cubierta de marfil de Adalbero II. (c) Laurianne Kieffer-Musée de La Cour d’Or-Metz Métropole Fig. 6: Evangeliario de Bernward de Hildesheim, Cod. 18, fol. 174. ( ) Dommuseum Hildesheim

64 Esta cubierta de marfil es la obra sobre la que gira el estudio de J. P. Caillet ya citado Aunque su análisis nada tiene que ver con el tema que estamos tratando, algunas de sus reflexiones son de una gran importancia para establecer la conexión entre Lotaringia y la transmutación semántica de la imagen que nos ocupa. CAILLET, J. P.: Metz et le travail... Op. cit., pp. 315-337. Fig. 1.

65 GOLDSCHMIDT, A.: Op. cit.,Tom.l., pp.43-44. Ilus. 78. En este caso la iconografía de la Tierra-Madre es muy similar a la del Nr 25067 del Victoria and Albert Museum y a la del Evangeliario de Metz. 

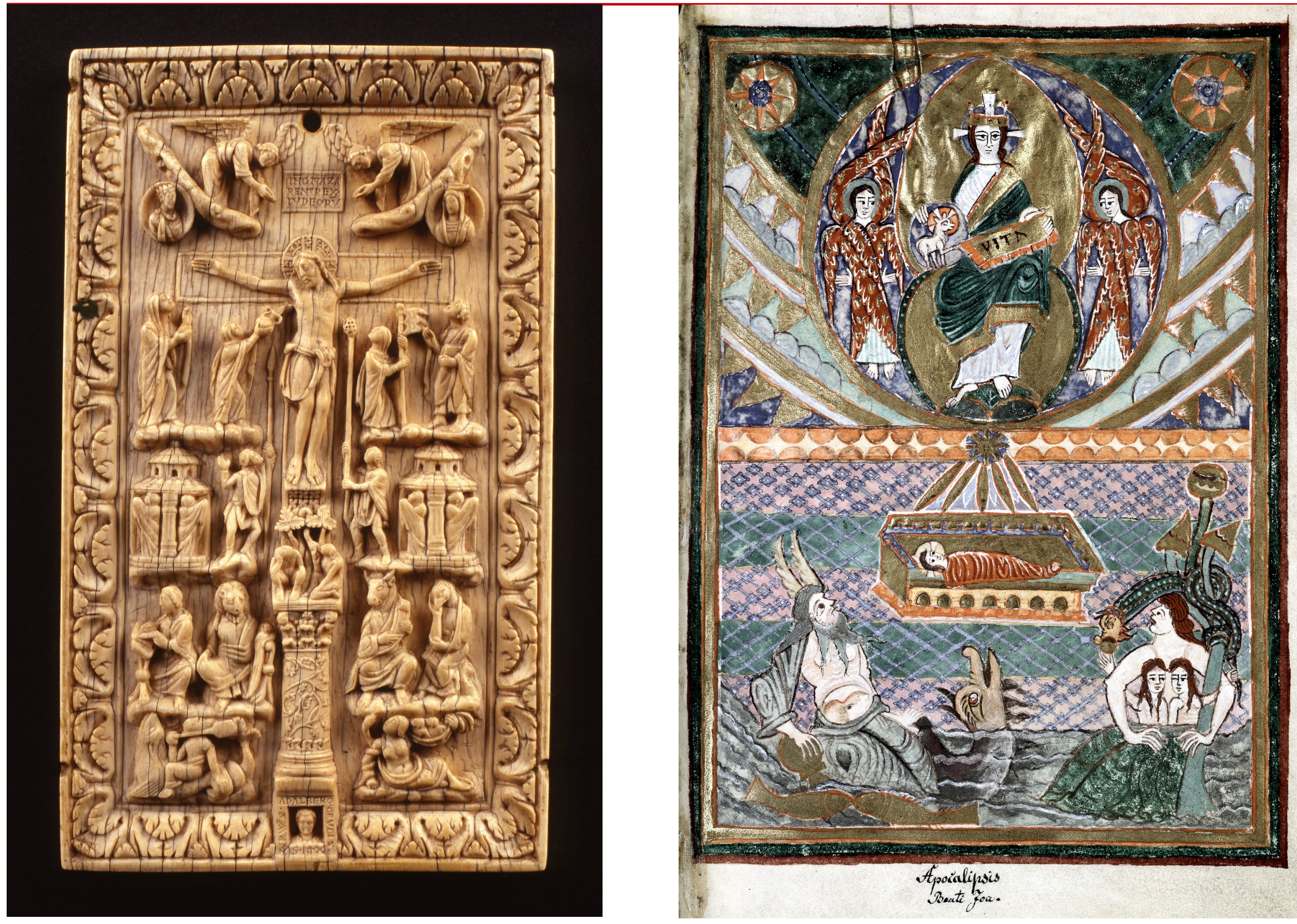
Dicha asociación va a persistir en algunas obras artísticas pertenecientes ya al ámbito otoniano, siendo una de las más significativas la miniatura que ilustra el fol. 174 del Cod. 18 conservado en el Tesoro de la Catedral de Hildesheim. Se trata del Evangeliario del obispo Bernward de Hildesheim y está datado hacia el año 1015. La miniatura corresponde el principio del Evangelio según San Juan y para ilustrar cómo el verbo se hizo carne la composición se ordena en dos registros superpuestos y claramente diferenciados que ilustran el encuentro entre lo eterno y la historia, entre lo natural y lo sobrenatural, entre Dios y el hombre: "En el cielo está Dios, intemporal y glorioso... En la parte de abajo el mundo visible, las fuerzas naturales donde yace el Mal, y que se resume en dos alegorías de inspiración antigua: el Océano montado sobre Leviatán y la Tierra que acoge en su seno a Adán y Eva, el árbol del Paraíso y la serpiente, es decir, los personajes y el escenario de la Caída...." ${ }^{66}$ (Fig. 6). Una vez más la naturaleza, lo visible y en definitiva lo terrenal, es visto por la mentalidad cristiana como algo maligno y negativo en contraposición a lo celestial, invisible o sobrenatural.

Ahora bien esta asociación no es la única relación que presentan ambas obras, ya que según el análisis de J.P. Caillet las relaciones iconográficas y estilísticas de la cubierta de marfil son mucho más evidentes con obras del ámbito lotaringio y otoniano que con las crucifixiones carolingias ${ }^{67}$. En este

66 DUBY, G.: Adolescencia del cristianismo occidental. 980-1140. Genéve-Barcelona, SkiraCarroggio, 1967, p. 184. A esta miniatura se refiere también WIRTH, K. A.: Reallexicon... Op. cit., p. 1034. Sorprende que Jacqueline Leclercq-Kadaner o Victoriano NodarFernández no hagan referencia a estas dos obras en las que la asociación entre el Pecado Original y la Tierra-Madre es tan evidente, cuando ambos hacen referencia a dicha asociación en sus respectivos estudios, sobre todo éste último en las pp. 342-343 de su artículo.

67 CAILLET, J. P.: Metz et le travail... Op. cit., p. 315 señala que en la publicación de A. Goldschmidt se atribuye a Metz una importante producción de obras escultóricas en marfil que pertenecen a dos etapas distintas: una primera escuela de Metz más o menos contemporánea al episcopado de Drogon y por lo tanto perteneciente a la sentido señala que la cubierta de marfil de Adalbero II muestra una vinculación directa con una serie de obras datadas entre el último tercio del siglo IX y principios del siglo $X$ que testimonian una evolución estilística que se produce durante algunos decenios únicamente en Lotaringia: tendencia a una organización estrictamente racional de la composición, una simetría absoluta o la presencia de figuras bien modeladas en relación al fondo del relieve. Una de las primeras obras en presentar dichas características sería la cubierta de marfil del ms.lat. 9383 ya citado ${ }^{68}$. Ahora bien entre la cronología de estas obras y el relieve de Adalbero II hay prácticamente un siglo de diferencia y aunque persistan algunas de las características ya señaladas, hay novedades que justifican su datación en torno al año 1000 siendo la más significativa la iconografía de Cristo crucificado. A la actitud rígida del Cristo de la tradición carolingia, un Cristo triunfante sobre la muerte y con los ojos abiertos, se contrapone ahora un

primera mitad del siglo IX y una segunda cuya cronología se extiende entre el último tercio del siglo IX y principios del siglo $\mathrm{X}$, pero cuyos ecos llegan a las proximidades del año mil. La hipótesis de Caillet es que existen en Lotaringia otros centros artísticos importantes por lo que en su opinión no se debe considerar la villa de Metz como único foco productor de estas obras. Expone la idea de lo arriesgado que resulta precisar centros o artistas concretos para las obras en marfil, ya que en su opinión a tratarse de un material exótico, únicamente disponible en momentos puntuales, su disponibilidad es bastante excepcional y convierte el trabajo en marfil en algo ocasional y esporádico, un trabajo que probablemente fuese desempeñado por un puñado de artistas que compaginaban la realización de este tipo de obras con la miniatura u otras especialidades suntuarias y que además también trabajaban de manera itinerante. Ver pp. 320-321 del artículo citado.

68 Completan el grupo la cubierta de marfil del ms.lat. 9453, conservado también en París, el relieve de un Evangeliario de Gannat o los ya señalados del Victoria and Albert de Londres. CAILlET, J. P.: Metz et le travail... Op. cit., Figs 3, 13, 12 y 14 respectivamente. El primer autor en establecer la hipótesis de dicha conexión fue FILLITZ, H.: "Die Wiener Gregor-Platte", dans Jahrbuch des Kunsthistorischen Sammlungen in Wien, 58 (N.F.22), 1962, pp. 7-22, aunque en principio las consideró obras del siglo $X$, cronología que se revisó y adelantó en base a la investigación que se llevó a cabo entre 1968 y 1971 de los marfiles del púlpito de San Pedro del Vaticano. 
Cristo del dolor con las rodillas flexionadas que presenta evidentes relaciones con el gran Cristo de Gero de la Catedral de Colonia, algo anterior al 976 y con la Crucifixión de plata dorada, precisamente de Bernward de Hildesheim, realizada hacia el 1007-1008 ${ }^{69}$.

La vinculación con estas obras otonianas resulta muy significativa, ya que algunas de las cubiertas de marfil realizadas en dicho ámbito artístico muestran representaciones de la Tierra-Madre con connotaciones negativas muy evidentes. Es el caso de la cubierta del Codex Aureus Epternacencis (Echternarcher Evangeliar) conservado en Nuremberg. Datada hacia el año 990 la imagen de la Tierra, identificada con su leyenda Terra, es una figura femenina que aparece sentada con las piernas cruzadas y soportando el peso de la Cruz de Cristo. Su gesto de sufrimiento y esfuerzo pone de manifiesto su culpabilidad, ya que el sacrificio del hijo de Dios recae sobre sus hombros ${ }^{70}$ (Fig. 7). En la imagen del Ms.A. 63 de la Königl Bibliothek de Dresde la Tierra-Madre aparece sujetando la serpiente, el maligno, que figura a los pies de la cruz y en la del Ms. Douce 292 de la Oxford Bodleian Library el Cristo triunfante de la Maiestas Domini saca el pie de la mandorla para pisar la cabeza de la figura de la TierraMadre que porta como atributos la rama florida y la serpiente ${ }^{71}$.

69 Esta nueva concepción de Cristo crucificado indica una mutación importante de la sensibilidad religiosa en Occidente, transformación puesta de manifiesto por la miniatura otoniana en los últimos decenios del siglo X. CAILLET, J. P.: Metz et le travail... Op. cit., pp. 316-318.

70 GOLDSCHMIDT, A.: Op. cit., Tom. II. Ilus. 23. GREBE, A.: Codex Aureus. Das Goldene Evangelienbuch von Echternach. Darmstadt, 2007, pp. 24-34.

71 El relieve de la Biblioteca de Dresde está datado a finales del siglo $X$ o principios del siglo XI. Por su parte el conservado en Oxford es de mediados del siglo XI y la actitud del Cristo de la Maiestas parece emular representaciones vinculadas al Salmo 91,13 en las que aparece pisando al león y al dragón o basilisco. Los dos en GOLDSCHMIDT, A.: Op. cit., Tom. II. Ilus. 86 y 51. A este último se refiere también WIRTH, K. A.: Reallexicon... Op. cit., p. 1042. Fig. 18.

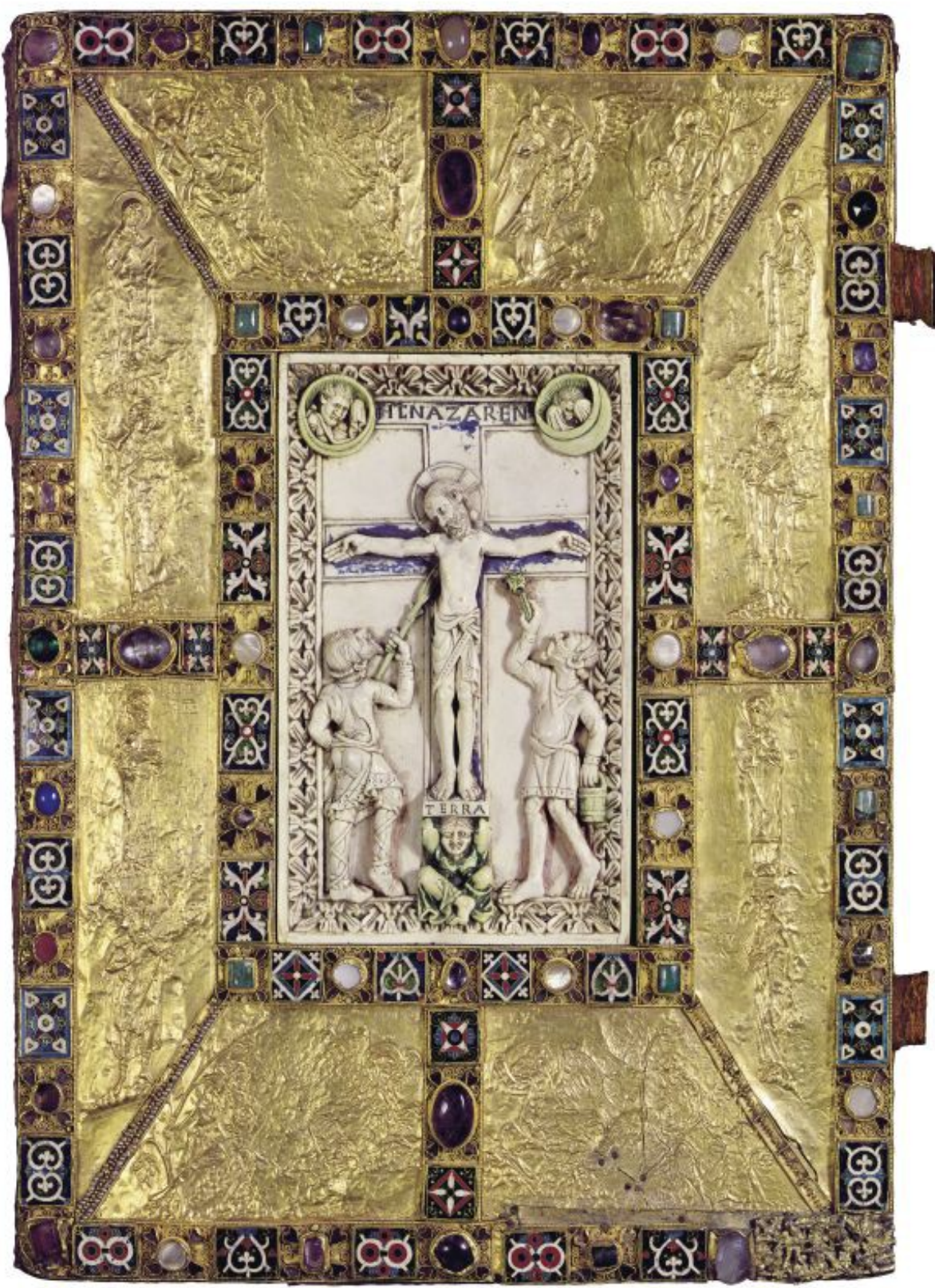

Fig. 7. Cubierta de marfil, Codex Aureus Epternacensis. Germanisches Nationalmuseum, Nürnberg 
De todo lo expuesto hasta ahora se desprende que la asociación más clara entre la figura de la Tierra-Madre y los protagonistas del Pecado Original se produce fundamentalmente en los marfiles realizados en el entorno de Lotaringia, una zona que por su situación geográfica, política y cultural sirve de puente entre Francia y Alemania, en la que a lo largo de los siglos $X$ y $X I$ se impulsa una importante reforma monástica con algunas particularidades y que va a extender su radio de acción tanto hacia los Países Bajos como hacia el espacio otoniano con el que mantiene evidentes contactos.

La visión que el pensamiento cristiano tiene del mundo terrenal, considerándolo manchado, contaminado desde el Pecado original propicia que la significación negativa de la Tierra-Madre sea ya muy clara a finales del siglo $\mathrm{X}$ y principios del siglo $\mathrm{XI}$ como lo testimonian los relieves otonianos. Sabemos que la mentalidad medieval considera el Pecado Original un pecado de concupiscencia carnal y por lo tanto un pecado de carácter sexual y ésta parece ser la razón fundamental para la transmutación semántica e iconográfica de la imagen de la Tierra-Madre en la de la femme-aux-serpents ${ }^{72}$.

72 Otras imágenes de referencia en las que la representación de la Tierra-Madre aparece frecuentemente amamantando diferentes tipos de animales son algunas miniaturas del Exultet, el Canto de la Vigilia Pascual que toma su nombre precisamente de las primeras palabras del texto "Exultet iam angelica turba coelorum". Este canto de la liturgia de la mañana del sábado de Pascua solía estar escrito e iluminado en rollos recogiendo la influencia del Rollo de Josué realizado en Constantinopla a mediados del siglo X. En ellos la Tierra-Madre, imagen de la fecundidad que da alimento a todas las criaturas, se convierte en una alegoría de la alegría de la Naturaleza ante la Resurrección de Cristo. A la influencia de las miniaturas de los Exultet se refieren: LECLERCQ-KADANER, J.: De la Terre... Op. cit., pp.39-40. NODAR FERNÁNDEZ, V.: De la Tierra-Madre... Op. cit., p.337-338. WEIR, A.; JERMAN, J.: Images of Lust. Op. cit., p. 6667. WIRTH, K. A.: Reallexicon... Op. cit.,p. 1034 y 1085. Para profundizar en los Exultet: AVERY, M.: The Exultet Rolls of South Italy. Princenton, 1936. SPECIALE, L.: Montecassino e la Riforma Gregoriana. L'Exultet Vat. Barb. Lat. 592. Roma, 1991. VV.AA.: Exultet, Rotoli liturgici del medioevo meridionale. Roma, 1994. OROFINO, G.:
Al periplo realizado por las referencias iconográficas susceptibles de haber podido influir en la transformación de esta imagen se han incorporado obras muy significativas que no habían sido consideradas hasta el momento en relación a este tema. Ahora bien, junto a las representaciones se deben señalar otras fuentes de referencia ya que existen textos que también pueden haber servido de inspiración a la gestación de la imagen de la femme-aux-serpents. En las Sagradas Escrituras algunos de los más elocuentes en relación a los pecados y sus consecuencias figuran en las

Exultet, teto e imagine nei rotoli ligurgici dell'Italia meridionale. Cassino, 1999 (CD Rom). Una de las miniaturas más significativas es el Barb. Lat. 592 de la Biblioteca Apostólica Vaticana. Datado entre 1058 y 1087 muestra a la Tierra-Madre surgiendo de una colina flanqueada por dos árboles y dando de mamar a un buey y a una serpiente. El mismo esquema iconográfico aparece ya en Exultet anteriores como el Vat.Lat. 9820 datado hacia el 985-987 o en el conservado en el Archivo de la Catedral de Bari, datado hacia el año 1000 y donde también flanquean su representación dos árboles. La incorporación de los animales a los que amamanta parece ser un poco posterior. NODAR FERNÁNDEZ, V.: De la Tierra-Madre... Op. cit., p.338-339 y 342 se refiere también a la imagen del Pecado Original del Exultet de la Biblioteca Apostólica Vaticana, pero ambas representaciones no presentan ninguna vinculación. WIRTH, K. A.: Reallexicon... Op. cit., p.1034. Fig. 14. Siguiendo la estela de las imágenes de los Exultet, la Tierra-Madre que aparece en uno de los manuscritos de la enciclopedia $D e$ naturis rerum de Rábano Mauro también amamanta a un buey o vaca y a una serpiente de cola retorcida. Datado en el 1023 este códice, ms.132, se conserva en Montecassino. LECLERCQ-KADANER, J.: De la Terre... Op. cit., p. 40. Fig. 3. WIRTH, K. A. Reallexicon... Op. cit., p. 1039. Fig. 17. En otro Exultet datado ya en el siglo XII, 724 B.I. 13 de la Biblioteca Casanatense de Roma, la Tierra-Madre sostiene una cornucopia florida mientras da de mamar a un buey y a un ciervo. LECLERCQ-KADANER, J.: De la Terre... Op. cit., pp.40. Fig.4. WEIR, A.; JERMAN, J.: Images of Lust... Op. cit., p.67. Ahora bien, aunque los Exultet también se asocien a un contexto Pascual y en ellos la TierraMadre aparezca amamantando a diversos animales y entre ellos a la serpiente, ninguna de estas representaciones conlleva la significación negativa que presenta su imagen asociada a los protagonistas del Pecado Original, incluido el relieve de la cubierta de marfil del Clm 4452, ya citado, donde amamanta a una serpiente y vinculado al pasaje del Génesis 3,14. Dicha cubierta, mencionada por casi todos los especialistas que se han ocupado de este tema, procede, además, del taller real de Carlos el Calvo, coronado como rey de Lotaringia en Metz en el año 869. 
Epístolas de San Pablo o en el Apocalipsis, aunque no refieran tormentos específicos ${ }^{73}$. Por ello va a ser en la tradición literaria de las visiones y los viajes al Más Allá donde vamos a encontrar las referencias más significativas $^{74}$. En este sentido queremos hacer hincapié en la existencia de una visión claramente explícita que hasta ahora ha pasado prácticamente desapercibida y que sin embargo resulta sumamente sugestiva por su cronología y su procedencia, aunque antes trazaremos el itinerario marcado por los textos recopilados en los estudios que han abordado este tema.

La visión permite recibir un mensaje especial del cielo, del tipo que sea, y normalmente tiene una doble finalidad: la primera puede ser personal o trascendente, buscando una rectificación del comportamiento o la perseverancia en el camino espiritual seguido por el visionario, visionario

73 Romanos 1, 26-31. 2 Corintios 11, 15. Ap. 6, 15.

74 Las visiones del cielo y el infierno y las comunicaciones con el Más Allá aumentan de manera significativa a partir del siglo VI llegando a constituir un género literario propio, "la literatura de visones". La bibliografía sobre este particular es amplísima, por lo que citaremos sólo algunos de los estudios más significativos: PATCH, H. R.: El otro mundo en la literatura medieval. México, 1956. GATTO, C.: "La voyage au paradis. La christianisation des traditions folkloriques au Moyen Age", Annales, 34, 1979, pp. 929942. LE DON, G.: "Structures et significations de l'imagerie médiévale de l'enfer", Cahiers de civilization médiévale, 22, 1979, pp. 363-373. LE GOFF, J.: La naissance du Purgatoire. París, 1981. Del mismo autor: "Aspects savants et populaires des voyages dans I'au-delá au Moyen Age", repris dans: L'imaginaire médiéval. París, 1985, pp. 103119. GOUREVITCH, A. J.: "Au Moyen Age: conscience individuelle et image de l'audelá", Annales, 37, 1982, pp. 255-275. DÍAZ DÍAZ, M.: Visiones del Más Allá en Galicia durante la Alta Edad Media. Santiago de Compostela, 1985. SEGRE, C.: Fuori del mondo. I modelli nella follia e nelle immagini dell'aldilá. Turín, 1990. CAROZZI, C.: Le Voyage de I'Âme dans I'au-delá. D'aprés la littérature latine (Ve-XIlle siécle), Collection de L'École Française de Rome, 189, 1994, una de las monografías más completas y exhaustivas sobre este tema. BASCHET, J.: Les Justices.. .Op. cit., Capítulos II y VIII fundamentalmente. TEJA, R. (coord.): Sueños, ensueños y visiones en la Antigüedad pagana y cristiana. Codex Aquilarensis № 18, 2002 (número monográfico) que en la mayor parte de las ocasiones pertenece al ámbito monástico. La segunda consiste en transmitir una enseñanza, un ejemplo a los hombres que pueden llegar a conocer su experiencia, por eso siempre hay un autor que es capaz de transcribir y adaptar las palabras del beneficiario de la visión. La predicación y la piedad popular descubren en estas visiones un medio eficaz para promover las prácticas religiosas y perseverar en la rectitud moral. Por eso el Cielo siempre es descrito con vivos colores y provisto de recursos que satisfacen todos los sentidos, mientras que en el Infierno se acumulan toda clase de tormentos y sensaciones desagradables y terroríficas ${ }^{75}$.

Un texto apócrifo citado por todos los autores que se han ocupado de este tema es el denominado Visio Sancti Pauli o Apocalipsis de san Pablo ${ }^{76}$. La versión original fue escrita en griego, probablemente en Egipto y parece ser de la primera mitad del siglo III, pero el manuscrito más antiguo que se conserva es un texto latino del siglo VIII que remonta la traducción a dicha lengua a comienzos del siglo VI. A partir del siglo IX se multiplican las redacciones cortas de las que se han distinguido hasta diez versiones diferentes de las cuales la más difundida es la Redacción IV. Su extraordinario éxito con versiones que se extienden hasta los siglos XII y XIII hace que la Visio Pauli sea considerada hoy un compendio de textos más que un texto antiguo concreto ${ }^{77}$.

75 DÍAZ DÍAZ, M.: Visiones del Más Allá... op. cit., pp. 9-20.

76 San Agustín lo considera una "fabulis plenam" y lo condena de manera rotunda. BASCHET, J.: Les Justices... op. cit., p. 90. nota 23. Como texto apócrifo aparece citado en el Decretum Gelasianum de principios del siglo VI.

77 La historia de este texto ha sido exhaustivamente analizada e investigada por T Silverstein. Una recopilación de sus numerosos estudios en: BASCHET, J.: Les Justices... Op. cit., p. 87. nota 6. Numerosos datos sobre la misma y su relación con visiones posteriores en: CAROZZI, C.: Le Voyage... Op. cit., p. 105-120, 225-261 y 265-279 para la Redacción VI. A la Visio Pauli se refieren también: WEIR, A.; JERMAN, J.: Images of Lust... Op. cit., p. 58. CASAGRANDE, C.; VECCHIO, S.: Histoire des... Op. cit., p. 351. GÓMEZ 
E. Male ya señaló que en dicha obra el tormento o suplicio de las serpientes era el castigo reservado a las madres solteras ${ }^{78}$. J. LeclercqKadaner amplió el espectro ya que en su opinión también incluía a las madres indignas y a las mujeres adúlteras ${ }^{79}$. Sin embargo uno de los problemas que presenta para considerarlo una fuente textual directa deriva fundamentalmente de sus numerosas versiones, ya que no todas refieren la mordedura en los senos de la mujer como suplicio o tormento concreto $^{80}$. De hecho ese castigo tan explícito no aparece en las versiones

GÓMEZ, A.: El protagonismo... Op. cit., p. 57. ARAGONÉS ESTELLA, E.: La Imagen del Mal... Op. cit., p. 139. MEYER, M.: "Porneia. Quelques considérations sur la représentation du péché de chair dans l'art byzantin", Cahiers de Civilisation Médiévale, 52, 2009, pp. 225-244. LUYSTER, A.: The Femme aux serpents... Op. cit., p. 176. Para ilustrar la diversidad de los textos haré referencia a dos versiones del párrafo relacionado con el motivo que estamos tratando: "Et vidit in alio loco viros ac mulieres, et vermes et serpentes comedentes eos", versión latina reseñada en WEIR, A.; JERMAN, J.: Images of Lust... Op. cit., p. 58. "Et vidim alium locum in quo omnes pene erant. Erantque ibi puelle nigre habentes vestimenta nigra, indute pice et sulfure et draconibus et igne et serpentibus atque viperis circa colla eorum", versión latina recogida en LUYSTER, A.: The Femme aux serpents... Op. cit., p.176.

78 MÂLE, E.: L'Art religieux du XII siécle... Op. cit.,p. 357. Recogido también por ADHÉMAR, J.: Influences... Op. cit., p. 198

79 LECLERCQ-KADANER, J.: De la Terre... Op. cit., p. 41, pero considerando también un texto posterior como es la Visión de San Alberico. Las referencias de esta autora son recogidas también por LUYSTER, A.: The Femme aux serpents... Op. cit., p. 175. Estudios posteriores como el de RODRÍGUEZ BARRAL, P.: Reflexiones... Op. cit., p. 13 generalizan el acoso de las serpientes a las mujeres que pecan contra la castidad.

80 A ello se refiere MONTEIRA ARIAS, I.: Las formas del pecado... Op. cit., pp. 57-58. En su estudio retoma hipótesis esbozadas hace algunas décadas que veían la influencia clara de los hadices árabes en las representaciones de los castigos a los pecadores de la iconografía cristiana. En su opinión es en estos textos teológicos musulmanes donde por primera vez se especifica la mordedura en los senos y los genitales, ya que en el infierno musulmán el tormento de los libidinosos consiste en ser picados y mordidos por serpientes y alacranes "en las partes de su cuerpo en que se besaron". Algunos de estos textos, redactados a partir del siglo VIII, describen la mordedura en los senos como castigo a las mujeres que se negaban a amamantar a sus hijos. La existencia de latinas y sí en alguna de las versiones francesas del siglo XIII en opinición de A. Luyster ${ }^{81}$. Dicha cronología lleva a pensar en la influencia que pudo recibir de textos del siglo XII que serán señalados más adelante, o también de las numerosas representaciones de este motivo iconográfico presentes ya en infinidad de iglesias románicas. De todas formas, y en base a la influencia que ejerció en numerosas visiones posteriores, es un texto a considerar ya que habla de tormentos y castigos infligidos por reptiles y asociados a hechos pecaminosos que entrarían dentro del amplio abanico de comportamientos vinculados al vicio de la lujuria.

Otros relatos apócrifos señalados, aunque en menor medida, son el denominado Apocalipsis de Pedro del siglo IV o el Descenso de la Virgen María al Infierno, texto del siglo IX incluido en algunos apócrifos sobre la dormición de la Virgen que dependen de la tradición griega y siríaca. En el primero se señala que bestias carnívoras castigarán y devorarán a las

paralelismos entre estos textos musulmanes y los de algunos exégetas cristianos como los del Monje de San Victor o San Alberico le lleva a considerar la influencia de los hadices en los textos cristianos. Por mi parte no dudo de las similitudes entre ambos, pero lo cierto es que los textos cristianos mencionados son ya del siglo XII, centuria en la que la iconografía de la femme-aux-serpents estaba ya plenamente codificada y difundida en el Occidente cristiano y además, nos consta la existencia de textos cristianos anteriores, textos a los que se va a hacer referencia en las páginas de este estudio.

81 LUYSTER, A.: The Femme aux serpents... Op. cit., pp. 176-178 donde analiza los castigos descritos en una de las versiones estudiadas por MEYER, P.: "La Descense de saint Paul en enfer", Romania, XXIV, 1895, pp. 365-375 para poner de manifiesto la asociación de este tormento a las malas madres. En una de las versiones francesas incluida en: BOVON, F.; GEOLTRAIN, P. (ed.): Écrits apocryphes chrétiens.. París, Gallimard, 1997. Tom.I., p. 814, los pecadores son atormentados por serpientes que se enrollan en diferentes partes de su cuerpo, pero no especifica la mordedura en los senos: "Je vis ensuite des hommes et des femmes revêtus de vètements clairs pleins de poix et de soufre enflammés et des serpents s'enroulaient autour de leurs cous, de leurs épaules et de leurs pieds". También: MEYER, M.: “Porneia...” Op. cit., p. 240. 
mujeres que han matado a sus hijos para toda la eternidad ${ }^{82}$. En el segundo el castigo consiste en monstruos, dragones o serpientes de dos cabezas que devoran los senos, castigo reservado a las mujeres prostitutas. Cuando la Virgen desciende al Infierno acompañada por San Miguel contempla este castigo y pregunta al arcángel quiénes son esas mujeres y cuál ha sido su pecado, a lo que el arcángel responde que han entregado su cuerpo a la prostitución y que por ello han sido condenadas al Infierno ${ }^{83}$. De los señalados hasta el momento éste es el texto más próximo en cuanto a la especificidad del castigo descrito y el más interesante por su cronología, ya que otros textos señalados por casi todos los autores que han analizado este tema, como son la Visión de Alberico de Montecassino o el párrafo escrito por un monje de Saint Victor son del siglo XII, momento en el que este motivo iconográfico goza ya de una inmensa difusión ${ }^{84}$.

82 El castigo incluye también a los maridos. "Le lait de leurs méres coulera de leurs seins, mais il caillera et il puera. II en sortira des bétes carnivores qui reviendront et les puniront elles et leurs maris pour la éternite, parce qu'elles ont transgressé le commandement du Seigneur et qu'elles on tué leurs enfants". Apocalypse de Pierre 8, 8-9. Versión francesa en Écrits apocryphes... Op. cit., p. 765. También: MEYER, M.: "Porneia..." Op. cit., p. 240. GUESURAGA, R.: La mujer con serpientes... Op. cit., pp. 2223.

83 MEYER, M.: "Porneia..." Op. cit., p. 240, nota 61 donde incluye la versión griega. La traducción francesa que utiliza es de PERNOT, H.: "Descente de la Vierge aux Enfers d 'aprés les manuscrits grecs de Paris", Revue des études grecques, 13, 1900, p. 252. Dicho texto ya fue reseñado por REAU, L.: Iconographie de l'Art Chrétien, en el Tomo II p. 729 de la edición francesa de 1957, dato que recoge ARAGONÉS ESTELLA, E.: La imagen del Mal.. .Op. cit., p. 139.

84 En la visión de Albéric de Settefrati, monje de Montecassino, y datada hacia 1130 es donde se especifica el castigo de las serpientes mordiendo las mamas de las mujeres que rechazan amamantar a sus hijos o a huérfanos sin madre. Por esta razón es recogido en numerosos estudios que analizan el tema de la lujuria. Entre ellos: ARAGONÉS ESTELLA, E.: La imagen del Mal.. .Op. cit., p.139. WEIR, A.; JERMAN, J.: Images of Lust...Op. cit., p.61. LECLERCQ-KADANER, J.: De la Terre... Op. cit., p.41. nota 46. LUYSTER, A.: The Femme aux serpents... Op. cit., pp. 178-179. ADHÉMAR, J.: Influences... Op. cit., p. 198, nota 2. CASAGRANDE, C.; VECCHIO, S.: Histoire... Op. cit., p.
A principios del siglo IX está datada otra visión significativa para este tema. Es la Visión de Wettin, con dos versiones en prosa y en verso datadas entre el 824 y el 827 . Está vinculada al círculo intelectual de Reichenau y a un autor con un papel destacado en la cultura carolingia, Walafrido Strabon, que además fue preceptor de Carlos el Calvo. En esta visión se señalan diversos castigos en los órganos sexuales: las mujeres que han seducido a sacerdotes son azotadas en esa parte de su cuerpo y a los que penan por adulterio, como es el caso del propio Carlomagno, los animales les desgarran dichos órganos. Pero además, en el capítulo XIX del viaje por el Más Allá que realiza el monje Wettin y cuando ya está regresando, el ángel que le acompaña realiza una exhortación moral destinada al pueblo cristiano que está centrada en la lujuria. El ángel comienza hablando del pecado "contra natura", del "vicio de Sodoma" por el que el género humano se ha separado de su Creador, pero lo equipara a otros pecados de la carne y acaba incluyendo en su radio de acción a los casados, cuyo lecho, inmaculado antes del Pecado se ha transformado, mancillado por el estupro, por lo que los esposos son prostituidos a los demonios. Y termina pidiéndole a Wettin que predique en público sobre los peligros de la lujuria en los $\operatorname{casados}^{85}$. Textos de este tipo ponen de manifiesto lo que he estado

351. GUESURAGA, R.: La mujer con serpientes.. . Op. cit., pp. 22-23. Datos específicos sobre este manuscrito en: CAROZZI, C.: Le Voyage... Op. cit., pp. 495-497. BASCHET, J.: Les Justices... Op. cit., pp. 103-108. En relación al extracto del texto de Hugo de Saint Victor, forma parte de su obra De Sacramentis, escrita entre 1135 y 1140 y refiere el castigo de la mordedura en los senos como suplicio para las cortesanas, por lo que tanto el tormento como las pecadoras coinciden con el texto del Descenso de la Virgen María a los Infiernos. Las referencias a esta obra en: CAROZZI, C.: Le Voyage... Op. cit., pp.532-533 y 552-553. Recogen también la traducción del pasaje concreto: ARAGONÉS ESTELLA, E.: La imagen del Mal... Op. cit., p.139. WEIR, A.; JERMAN, J.: Images of Lust... Op. cit., p.61.

85 A la Visión de Wettin se refieren: GUESURAGA, R.: La mujer con serpientes... Op. cit., pp. 19-20. BASCHET, J.: Les Justices... Op. cit., p.100 y sobre todo CAROZZI, C.: Le Voyage. Op. cit., pp.324-331, con numerosos datos, la descripción del "viaje" y la significación y dimensión política del mismo. 
señalando a lo largo de estas páginas, que es todo un entorno de pensamiento y no sólo la descripción específica de un tormento concreto lo que explica la transformación semántica de esta imagen. Además demuestra que la asociación entre el castigo en los órganos sexuales y los pecados de la carne ya estaba circulando en textos carolingios, textos que pertenecen a un momento significativo para dicha variación.

A estos textos debemos añadir la existencia de otra fuente de referencia claramente explícita de la segunda década del siglo $\mathrm{XI}$, fuente que incomprensiblemente ha pasado bastante desapercibida. La recogía Werner Weisbach y la incluye Raphaël Guesuraga, de forma muy escueta, en uno de sus artículos. En mi opinión es de suma importancia, ya que describe el castigo de la mordedura en los senos que sufren las meretrices y las mujeres adúlteras y asocia, una vez más, a la mujer con los pecados de la carne. Me refiero a la Crónica del abad Hugo de Flavigny, Crónica que incluye dos relatos de sendos monjes que, gravemente enfermos y en un momento de éxtasis, experimentan visiones del Infierno y describen distintos castigos $^{86}$. Es en la visión de 1012 y en la segunda descripción del Infierno donde hay un pasaje específico en el que se refiere a la lujuria que pena en una corriente helada -aspecto éste que posteriormente será incluido también en la Visión de San Alberico de Montecassino- y en el que refiere el ataque de serpientes a los senos de las mujeres deshonestas: "Harum mamillas, anteriora quoque et posteriora per horrendia multi generis monstra et cohabitantium maxima multitudo acceperant

86 CAROZZI, C.: Le Voyage... Op. cit., p. 396 señala que Hugo de Flavigny inserta en su Crónica dos cartas del Abad de Saint-Vanne de Verdun, Richard. Dichas cartas, enviadas a los monasterios que este abad había reformado, recogen el testimonio de dos visiones, una de 1011 y otra de 1012, visiones que habían tenido sendos monjes de Saint-Vaast d'Arras. Para el contenido de las dos visiones ver pp. 396-412 de su estudio. El análisis más completo sobre la Crónica es el de HEALY, P.: The Chronicle of Hugh of Flavigny: Reform and the Investiture Contest in the Late Eleventh Century. Londres, Ashgate, 2006. devoranda". El monje le pregunta quiénes son esas mujeres y el ángel le contesta: "Hae sunt meretrices, quas vides, quarum mamillas tortines lacerant serpentes, quia peccaverunt per carnem et adulteria adulteraverunt magna" ${ }^{87}$.

Merece la pena reparar brevemente en las figuras de Hugo de Flavigny y el abad Richard de Saint-Vanne de Verdún para constatar el contexto espiritual en el que se insertan las dos visiones y la composición de la Crónica del abad de Saint Pierre de Flavigny. Hugo de Flavigny, nacido hacia 1060 cerca de Verdún, fue monje en el monasterio de Saint-Vanne de Verdún y después en el de Saint-Benigne de Dijon. El primero de estos monasterios, fundado en el año 952, es una de las abadías que más contribuye a difundir la reforma monástica en Lotaringia, precisamente bajo el mandato del abad Richard entre los años 1004 y 1046. El abad Richard es el responsable de la reforma y el desarrollo del monasterio de Saint-Vanne a través de la consecución de reliquias, el culto a los santos y

87 WEISBACH, W.: Reforma religiosa... Op. cit., notas 121 y sobre todo 237 citando como fuente: PERTZ, G. H.(ed.): Chronicon. Monumenta Germaniae Historica, Scriptores, VIII, Hanovre, 1848, p. 389. Dicha Crónica se conserva en la Staatsbibliothek de Berlín (MS Meerman 142). Por su parte GUESURAGA, R.: La mujer con serpientes... Op. cit., p. 22 cita la visión de un monje de Saint-Vaast d'Arras de comienzos del siglo XI, aunque no señala su inclusión en la Crónica de Hugo de Flavigny. Apunta que las mujeres con los pechos devorados por monstruos horribles y una multitud de serpientes son adúlteras o prostitutas y más adelante subraya, que en los textos, las mujeres castigadas por pecados sexuales son mayoritariamente prostitutas o cortesanas. Sinceramente no entiendo muy bien la intención de esas precisiones cuando en la visión que nos ocupa, y además de las prostitutas, también se habla de mujeres adúlteras y más precisamente de las que han cometido pecados carnales. En mi opinión, y ya lo he señalado, la concepción de la lujuria en aquel momento incluye todos estos comportamientos deshonestos y que sean castigadas bien por seducción, por fornicación, por ser malas madres, por adúlteras o por prostitución no es la cuestión más relevante, que sigue siendo la vinculación entre el género femenino, la tentación, el sexo y el pecado y las estrategias escritas o figurativas que se despliegan para ponerlo de manifiesto de una manera contundente. 
el impulso otorgado a su scriptorium y a su escuela monástica. Además de fervoroso reformista, difundió su ideal monástico por otras abadías de la Baja Lotaringia y del Noreste de Francia, labor en la que colaboraron algunos de sus discípulos y entre los cuales destaca Léduin, un monje precisamente de Saint-Vaast de Arrast, cuya reforma impulsó el abad Richard a partir de $1018^{88}$. No es extraño por lo tanto que Hugo de Flavigny, claramente partidario de la renovación y regeneración de la Iglesia, incluyera en sucrónica dos cartas del abad responsable de la transformación y reforma de la abadía en la que había iniciado su monacato y su formación ${ }^{89}$.

88 Su labor reformista abarca, además de la diócesis de Verdún, la diócesis de Lieja y Cambrai, Normandía o Chalons-sur-Marne. Había sido canónigo de Reims y parece ser que fue su relación con Odilón de Cluny la que le impulsó hacia el monacato y a trabajar por organizar y difundir la reforma monástica. Para la figura de Richard de Saint-Vanne ver: DAUPHIN, H.: Le Bienheureux Richard abbé de Saint-Vanne de Verdun. Lovaina-París, 1946. FLAMMARION, H.: "Les sources narratives en Lorraine autor de I 'an Mil", dans: Religion et Culture autor de l'an Mil. Royaume capétien et Lotharingie. París, Picard, 1990, pp. 301-308.TURCAN-VERKERK, A. M.: "Le Scriptorium de SaintVanne de Verdun sous l'abbatiat de Richard (1004-1046)", Scriptorium, t. 46, 1992, pp. 204-223. REILLY, D. J.: "The Art of Reform in Eleventh-Century Flanders: Gerard of Cambrai, Richard de Saint-Vanne and the Saint-Vaast Bible", in: Studies in the History of Christian Traditions, Vol. 128, Leiden:Brill, 2006. WAGNER, A.: "Richard de Saint-Vanne (1004-1046) et l'esprit de sa reforme", dans: L'ecrit et le livre peint en Lorraine, de Saint-Mihiel á Verdun (IXe-XVe siecles). Actes du Colloque de Saint-Mihiel (25-26 octobre 2010), Brepols Publishers, 2014, pp. 105-120. La última monografía publicada sobre el abad Richard es la de VANDERPUTTEN, S.: Imagining Religious Leadership in the Middle Ages. Richard of Saint-Vanne and the Politics of Reform. Cornell University Press, 2015.

89 La biografía del abad Richard incluida en la Crónica se inscribe dentro de un discurso destinado a precisar y explicar cuál es la posición del propio Hugo de Flavigny ante los debates que se están produciendo en torno a la vida monástica a finales del siglo XI. DAUPHIN, H.: Le Bienheureux... Op. cit., pp. 20-26. Asimismo, el testimonio de las dos visiones refleja la tensión escatológica que se vive a comienzos de siglo, con una atmósfera un tanto enrarecida para los monjes reformistas que se encuentran con no pocas dificultades para imponer sus ideales monásticos y donde la angustia de los visionarios queda reflejada en los escritos, ya que la confrontación entre monjes y
Tanto Saint-Vanne como Saint-Bénigne de Dijon eran monasterios afines a su ideario monástico y su permanencia en éste último le proporcionó además la amistad del abad Jarento y contacto con figuras tan destacadas como el abad Hugo de Cluny. Además de cronista, en diversas ocasiones ejerció como secretario del abad Jarento y del arzobispo Hugo de Lyon entre 1085 y 1096, labor que le permitió conocer de primera mano los entresijos de la política religiosa del momento. Todo ello le llevó a la desilusión y el desengaño ante el clero "reformista", a criticar en su Crónica la avaricia de la curia romana y a renegar de su amistad con Hugo de Lyon por el trato que éste mantenía con clérigos simoníacos ${ }^{90}$.

Lotaringia vive entre mediados del siglo X y el siglo XI una "edad dorada" en la que su importancia cultural e intelectual llega más allá de sus fronteras. Su situación geográfica y política contribuye a que sea una zona de recepción y difusión de distintas corrientes artísticas y de pensamiento. El propósito de esta contribución es poner de manifiesto que juega un papel muy significativo en la transmutación iconográfica y semántica de la imagen analizada, ya que se ha constatado que en esta zona confluyen una serie de evidencias que parecen ser determinantes:

laicos se muestra sin ambigüedades en el diálogo de la primera Visión entre el alma y san Miguel cuando ésta le pregunta ¿Quis est serpens? y el arcángel le responde Laici homines sunt. CAROZZI, C.: Le voyage... Op. cit., pp. 411-412.

90 Fue testigo presencial de una petición de Urbano II al abad Jarento encomendándole la misión de reformar la iglesia de Inglaterra, cuyo monarca se apropiaba de rentas eclesiásticas y toleraba la simonía y el nicolaísmo. El rey Guillermo, ante esta intromisión, envió en secreto 10 marcos de oro al Papa, por lo que Urbano Il encargó a su propio sobrino que anulase la misión del abad Jarento. Por su parte Hugo de Lyon era supuestamente uno de los más ardientes defensores de la reforma de la Iglesia, su exceso de celo reformista le había llevado a ser censurado por el propio Gregorio VII, pero sus conflictos con la Sede de Roma le llevaron a buscar apoyo en clérigos claramente simoníacos y corruptos como Norgardo de Autun. Ver: HEALY, P.: The Chronicle of Hugh of Flavigny... Op. cit., pp. 19-21 y 63-88. GONZÁLEZ GARCÍA, A.: "E Papa Urbano II y el origen de la Garcineida", Anuario de Estudios Medievales 43/2, 2013, pp. 620 y 624-25. 
Las representaciones de la segunda mitad del siglo IX en las que la TierraMadre aparece amamantando a los dos pequeños personajes que se han identificado como Adán y Eva están vinculadas a la Escuela de Palacio de Carlos el Calvo, rey de Lotaringia a partir del año 869, al igual que la cubierta de marfil en la que amamanta a una serpiente y que ha sido relacionada con el pasaje del Génesis 3,14 en el que se condena a este animal por el Pecado Original. Dicha fórmula iconográfica perdura durante el siglo $X$ en relieves de su área de influencia.

La iconografía de la Tierra-Madre con la serpiente enroscada en el brazo y cobijando a estos pequeños personajes es visible en cubiertas de marfil realizadas en Metz o en otros centros importantes de Lotaringia en el último tercio del siglo IX y además dichas representaciones muestran relaciones evidentes con las del grupo anterior.

La cubierta de marfil de Adalbero de Metz, datada hacia el año 1000, muestra también claras vinculaciones con las obras realizadas en la denominada Segunda Escuela de Metz, pero incorpora además novedades presentes en el arte otoniano, ya que estudios realizados sobre dicha cubierta han puesto de manifiesto su relación con el crucifijo de plata dorada del obispo Bernward de Hildesheim, cuyo Evangeliario, como ya se ha visto, incluye una miniatura donde la asociación entre la Tierra-Madre y el Pecado Original es evidente. Se sabe asimismo que dicho obispo recurrió a un viejo monje alemán de Fleury para que le explicase la forma de vida y las costumbres del célebre monasterio con el propósito de impulsar la reforma de alguna abadía de su diócesis ${ }^{91}$. Resulta llamativo que estas dos obras no hayan sido considerados hasta ahora en los estudios centrados en analizar este tema iconográfico.

91 Ver: DONNAT, D. L.: Les coutumes... Op. cit., pp.19 y 23.
En algunos marfiles otonianos de finales del siglo $\mathrm{X}$ e inicios del siglo XI la iconografía de la Tierra-Madre presenta ya unas connotaciones claramente negativas y asociadas a su consideración de lugar para el pecado, tal como lo puso de manifiesto san Pablo en Colosenses 3, 5 haciendo hincapié fundamentalmente en los pecados de la carne.

La dos visiones de comienzos del siglo XI que provienen de Saint-Vaast de Arras fueron probablemente escritas ${ }^{92}$ y desde luego difundidas por el propio Richard de Saint-Vanne en los monasterios que él había reformado, monasterios que como ya se ha visto se extienden por un zona bastante amplia que abarca el Nordeste de Francia, Lotaringia y se amplía hacia el Imperio otoniano.

De todo ello se desprende que la asociación de la Tierra-Madre al Pecado Original y su consideración de algo manchado, contaminado, que nutre y cobija los comportamientos pecaminosos, se va gestando a lo largo de los siglos IX y X para ser ya claramente explícita en los albores del siglo XI y en las representaciones de una zona geográfica que, sorprendentemente, es la misma por la que se difunde, al compás de la reforma monástica, un texto escrito del año 1012 que asocia explícitamente el castigo de los senos devorados por serpientes con las mujeres y los pecados de la carne.

La transformación de la imagen antigua, la que legitimaba su uso como iconografía de referencia, se ha ido alterando al ritmo marcado por el proceso reformista y su mentalidad, una mentalidad que va a desplegar diferentes estrategias para inculcar su ideario ascético y advertir sobre los

92 Así parece considerarlo CAROZZI, C.: Le Voyage... Op. cit., p. 407 en relación a la visión de 1012, algo muy probable ya que a Richard de saint-Vanne se le atribuyen entre otras obras, la redacción de una Vida de saint Vanne, obispo de Verdún y patrono de su abadía, una Vida de saint Rouin o una Vida de saint Saintin, primer obispo de Verdún todas ellas de la primera mitad del siglo XI. FLAMMARION, H.: Les sources... Op. cit., p. 303. 
peligros de la carne. Una de las más contundentes será concebir la femmeaux-serpents, probablemente el suplicio más horripilante y humillante que una mujer pueda recibir. Su iconografía aparece ya perfectamente codificada en el último tercio del siglo XI y la apuesta de estos monjes reformistas por la consolidación de los Caminos de Peregrinación y en especial por el Camino de Peregrinación a Santiago de Compostela, propiciará que algunos de los ejemplos más tempranos aparezcan en centros tan destacados como Toulouse, Jaca, Frómista, San Isidoro de León o la propia Compostela y que su difusión sea muy significativa en torno a las diferentes vías del Camino. 


\section{BIBLIOGRAFÍA}

ADHÉMAR, J.: Influences antiques dans l'art du Moyen Âge français. London, The Warburg Institute, 1939.

ANGHEBEN, M.: Les chapiteux romans de Bourgogne. Thémes et programmes. Brepols, Turnhout, 2003.

ARAGONÉS ESTELLA, E.: La imagen del Mal en el Románico Navarro. Pamplona, Gobierno de Navarra, 1996.

AUBERT, J .M.: La femme. Antiféminisme et Christianisme. París, 1975.

AVERY, M.: The Exultet Rolls of South Italy. Princenton, 1936.

BARONE, G.: "Gorze e Cluny a Roma", dans: Retour aux sources. Textes, études et documents l'histoire médiévale offerts á Michel Parisse. Ed. Par Sylvain Gouguenheim et. al. París, 2004, pp. 583-590.

BASCHET, J.: Les Justices de l'au-delá. Les Representations de l'enfer en France et en Italie (XIIle-XVe siécles). Roma, École française de Rome, 1993.

: L'iconographie médiévale. París, Gallimard, 2008.

BENEDETTO, P.: Matrimonio e continenza nel cristianesimo delle origine. Studi su I Cor. 7, 1.40. Brescia, 1979.

BETETA MARTíN, Y.: "Súcubos, hechiceras y monstruos femeninos. Estrategias de desautorización femenina en el exemplum medieval", en: La Querella de las Mujeres I. Análisis de textos. Madrid, AlMudayna, 2010.
BORNAY, E.: Las hijas de Lilith. Madrid, Ensayos Arte Cátedra, 2004.

BOVON, F.; GEOLTRAIN, P. (ed.): Écrits apocryphes chrétiens. París, Gallimard, 1997.

BROWN, P.: El cuerpo y la sociedad: los hombres, las mujeres y la renuncia sexual en el cristianismo primitivo. Barcelona, Ensayo, 1993.

CAILLET, J. P.: "Metz et le travail de l'ivoire vers l'an Mil", dans Religion et Culture autor de I'an Mil. Royaume capétien et Lotharingie. París, Picard, 1990, pp. 315-337.

CAROZZI, C.: Le Voyage de l'Âme dans l'au-delá. D'aprés la littérature latine (Ve-XIIle siécle). Roma, Collection de l'École Française de Rome, 189 (1994).

CARRILLO LISTA, Mạ. P.; FERRÍN GONZÁLEZ, J. R.: “Algunas representaciones de vicios en el románico gallego: la lujuria", Anuario Brigantino, $n$ o 19, 1996, pp. 235-244.

: "La figura de la mujer con serpientes y el castigo de la lujuria en el Arte Románico", en: La vida cotidiana en la España Medieval. Madrid, Actas del VI Curso de Cultura Medieval, 1998, pp. 391-408.

CASAGRANDE, C.; VECCHIO, S.: Histoire des péchés capitaux au Moyen Âge. París, Flammarion, 2003.

CASANOVA, E.; LARUMBE, Ma.A.: La serpiente vencida. Sobre los orígenes de la misoginía en lo sobrenatural. Prensas Universitarias de Zaragoza, 2005. 
CASTIÑEIRAS, M.: El tapis de la Creació/ El tapiz de la Creación. Girona, 2011.

COLIN-GOGUEL, F.: L'image de l'Amour charnel au Moyen Âge. París, Seuil, 2008.

CORTÉS ARRESE, M.: "Imágenes de los infiernos en el arte bizantino", Codex Aquilarensis, № 11, 1994, pp. 151-174.

: "Imagen de los infiernos en el arte bizantino", XX Siglos, Vol. 7, № 29, 1996, pp. 29-42.

CUADRADO LORENZO, Ma. F.: "Tres esculturas de Leire y sus relaciones con temas escatológicos", Príncipe de Viana, no 199, 1993, pp. 229-245.

D'ALVERNY, M. Th.: "Comment les théologiens et les philosophes voient la femme", Cahiers de Civilisation Médiévale, no 20, 1977, pp. 105-129.

DAUPHIN, H.: Le Bienhereux Richard abbé de Saint-Vanne de Verdun. Lovaina- París, 1946.

DELHAYE, Ph.: "Le dossier antimatrimonial de l'Adversus Jovinianum" et son influence sur quelques écrits latins du XII siécle", Mediaeval Studies, 13, 1951, pp. 65-86.

DEL OLMO GARCÍA, A.: Iconografía sexual en el Románico. Salamanca, 1999.

DEL VAL VALDIVIESO, Mạ. I.: "El Mal, el Demonio, la Mujer (en la Castilla Bajomedieval)", en: Vivir siendo mujer a través de la Historia. (Coord. Ma. I. Del Val; C. De la Rosa; M. J. Dueñas), Universidad de Valladolid, 2005, pp. 13-40.
DÍAZ DÍAZ, M.: Visiones del Más Allá en Galicia durante la Alta Edad Media. Santiago de Compostela, 1985.

DIMANUEL JIMÉNEZ, M.: “Iconografía erótica en la Edad Media", Liceus, Portal de Humanidades, 2006.

DUBY, G.: Adolescencia del cristianismo occidental. 980-1140. GéneveBarcelona, Skira-Carroggio, 1967.

El Caballero, La Mujer el Cura. El matrimonio en la Francia feudal. Madrid, Taurus, 1982.

FOUCAULT, M.: Histoire de la sexualité. Tom.II: L'Usage des plaisirs. París, Gallimard, 1984.

FRUGONI, C.: "L'iconographie de la femme au cours des Xe-Xlle siécles", Cahiers de Civilisation Médiévale, no 20, 1977, p. 177-188.

GATTO, C.: "La voyage au paradis. La christianisation des traditions folkloriques au Moyen Âge", Annales, 34, 1979, pp. 929-942.

GIORDANO, O.: Higiene y buenas maneras en la Alta Edad Media. Madrid, Gredos, 2001.

GOLDSCHMIDT, A.: Die Elfenbeinskulpturen aus der Zeit der Karolingischen und sächsischen Kaiser, VIII-XI Jahrhundert. Berlín, Deustscher Verlag, 1969.

GÓMEZ, N. M.: "La representación del infierno devorador en la miniatura medieval", Memorabilia 12, 2009-2010, pp. 269-287.

GÓMEZ GÓMEZ, A.: El protagonismo de los otros. La imagen de los marginados en el arte románico. Bilbao, 1997. 
:"La iconografía del parto en el arte románico hispano", Príncipe de Viana, no 213, 1998, pp. 79-101.

GONZÁLEZ ZYMILA, H.: "Tradición clásica en la serpiente del Medievo", Revista de Arqueología, no 260, 2002, pp. 46-53.

GOUREVITCH, A. J.: "Au Moyen Âge: conscience individuelle et image de I 'au-delá", Annales, 37, 1982, pp. 255-275.

GREBE, A.: Codex Aureus. Das Goldene Evangelienbuch von Echternach. Darmstadt, 2007.

GUESURAGA, R.: “Los hombres con la cabeza devorada por dragones, una representación del enemigo simoniaco en la escultura románica. Sinopsis de una hipótesis", Románico, no 11, 2010, pp. 24-31.

: "La mujer con serpientes y sus dudosas relaciones con la lujuria", Románico, no 17, 2013, pp. 17-23.

: "La mujer con serpientes y los clérigos nicolaítas", Románico, no 18, 2014, pp. 16-23.

HEALY, P.: The Chronicle of Hugh of Flavigny: Reform and The Investiture Contest in the Late Eleventh Century. Londres, Ashgate, 2006.

HERRERO MARCOS, J.: La lujuria en la iconografía románica. Palencia, Cálamo, 2011.

HUERTA HUERTA, P. L.: “Las visiones infernales: Pecados, pecadores y tormentos", en: Poder y seducción de la imagen románica. Aguilar de Campoo, 2006, pp. 81-116.

KAPLISCH-ZUBER, C.:"Masculino/ Femenino", en: Diccionario razonado del Occidente Medieval. Madrid, Akal, 2003, pp.507-515.
KENT, B.: "On the Track of Lust: Luxuria, Ockaham, and the Scientistis", In: The Garden of Evil. The Vices and Culture in the Middle Ages. Ed. by R. Newhauser. Toronto-Ontario, Pontifical Institute of Mediaeval Studies, 2005, pp. 349-370.

KESSLER, H. L.: Spiritual Seeing. Picturing God's Invisibility in Medieval Art. Philadelphia, 2000.

: "Speculum", Speculum, 86, 2011, pp. 1-41.

LECLERCQ-KADANER, J.: "De la Terre-Mére á la Luxure. A propos de "la migration des symboles", Cahiers de Civilisation Médiévale, XVIII, 1975, pp. 37-43.

LE DON, G.: "Structures et significations de l'imagerie médiévale de I 'enfer", Cahiers de Civilisation Médiévale, 22, 1979, pp. 363-373.

LE GOFF ,J.: La naissace du Purgatoire. París, 1981.

: “Aspects savants et populaires des voyages dans l'au-delá au Moyen Âge”, dans: L'imaginaire médiéval. París, 1985, pp. 103-119.

LE GOFF, J.; TRUONG, N.: Una historia del cuerpo en la Edad Media. Barcelona, Paidós, 2005.

LYMAN, Th. W.: "Motiv et narratif. Vers una typologie des thémes profanes dans la sculpture monumentale de Los Romerías", Cahiers de Saint Michel de Cuxa, no 10, 1979, pp. 59-78.

Los caminos de la exclusión en la sociedad medieval: pecadol delito y represión. XXII Semana de Estudios Medievales, Nájera, 2011, Logroño, Instituto de Estudios Riojanos, 2012. 
LUYSTER, A.: "The Femme- aux-Serpents at Moissac: Luxuria (Lust) or a Bad Mother?", in: Between Magic and Religion: Interdisciplinary Studies in Ancient Mediterranean Religion and Society. Ed. S. Asirvatham; C.O. Pache; J. Wartrous. Oxford, Roeman\&Littlefield Publishers, 2001, pp. 165-191.

MÂLE, E.: L'Art religieux du XII siécle en France. Étude sur les origines de I 'iconographie du Moyen Âge. París, A. Colin, 1922.

MARCOS SÁNCHEZ, M. del M.: "La visión de la mujer en San Jerónimo a través de su correspondencia", en: La mujer en el Mundo Antiguo. Actas de las $V$ Jornadas de Investigación Interdisciplinar, Madrid, 1986, pp. 315-322.

: "Caracterización del sexo femenino en la correspondencia de San Jerónimo", VII Congreso Español de Estudios Clásicos, Vol. 3, 1989, pp. 211-216.

MARTÍNEZ DE LAGOS, E.: Ocio, diversión y espectáculo en la escultura gótica. Bilbao, Universidad del País Vasco, 2007.

: "La femme aux serpents". Evolución iconográfica de la representación de la lujuria en el Occidente europeo medieval", Clio\&Crimen, no7, 2010, pp. 137-158.

: "Discursos visuales y mentalidad religiosa. La femme-aux-serpents y el uso de imágenes antitéticas en la escultura románica", Brocar, no 38,2014 , pp. 45-64.

MEYER, M.: "Porneia". Quelques considérations sur la représentation du péché de chair dans l'art byzantin", Cahiers de Civilisation Médiévale, 52, 2009, pp. 225-244.
MEYER, P.: "La Descense de Saint Paul en enfer", Romania, XXIV, 1895, pp. 365-375.

MIRANDA, L.R.: “¿Cuál fue el Pecado Original? Traducciones e interpretaciones de Gn 3, 1-24", Circe, no 13, 2009, pp. 157-171.

MOLINIÉ, S.: "L'image de la femme luxurieuse et tentatrice dans la sculpture romane du Midi de la France", Revue d'Auvergne, no 586, 2008, pp. 109-124.

MONTEIRO ARIAS, I.: "Las formas del pecado en la escultura románica castellana. Una interpretación contextualizada en relación con el Islám", Codex Aquilarensis, no 21, 2005, pp. 51-83.

MORAL DE CALATRAVA, P.: La mujer imaginada. La construcción cultural del cuerpo femenino en la Edad Media. Murcia, Nausicaä, 2008.

MORÁN MORÁN, J.: La recuperación de la "Ecclesiae Primitivae Forma" en la escultura del Panteón Real de San Isidoro de León. León, 2008.

MORÁN O.S.A., J.: Obras de San Agustín. La ciudad de Dios. Madrid, B.A.C, 1964.

NEISKE, F.: "Réforme clunisienne et réforme de l'Eglise au temps de l'abbé Hugues de Cluny", en: La reforma gregoriana y su proyección en la Cristiandad Occidental. Siglos XI-XII. XXXII Semana de Estudios Medievales (Estella, 2005), Pamplona, Gobierno de Navarra, 2006, pp. 335-359.

NEWHAUSER R. (ed.): In the garden of evil. The vices and culture in the Middle Ages. Toronto-Ontario, Pontifical Institute of Mediaeval Studies, 2005. 
NODAR FERNÁNDEZ, V.: "De la Tierra Madre a la Lujuria: a propósito de un capitel de la girola de la Catedral de Santiago", Semata, Vol. 14, 2002, pp. 335-347.

NUET BLANCH, M.: "San Antonio tentado por la lujuria. Dos formas de representación en la pintura de los siglos XIV y XV", Locus Amoenus, 2, 1996, pp. 111-124.

NUÑO GONZÁLEZ, J.: "Hacia una visión de la iconografía sexual: escenas procaces y figuras obscenas", en: Poder y seducción de la imagen románica. Aguilar de Campoo, Fundación Santa María la Real, 2005, pp. 193-226.

OAKESHOTT, W.: Classical Inspiration in Medieval Art. New York, Frederick A. Praeger, 1960.

OLMO GARCíA, A. del.: Iconografía sexual en el Románico. Salamanca, 1999.

OLMO GARCÍA, A. del.; VARAS, B.: Románico erótico en Cantabria. Palencia, 1988.

OROFINO, G.: Exultet, teto e imagine nei rotoli liturgici dell'Italia meridionale. Cassino, 1999. (CD. Rom).

PACE, V.: "Immagini della sessualitá nel Medioevo italiano", en: Medioevo: immagini e ideologie. Atti del Conv. Int. Di Studi, Parma, 2002, Milán, Electa, 2005, pp. 630-643.

PALAZZO, E.: "Art, Liturgy and the Five Senses in the Early Middle Âges", Viator, 41(1), 2010, pp. 25-56.
: "Visions and Liturgical Experience in the Early Middle Âges", in: Looking Beyond. Visions, Dreams and Insights in Medieval Art and History. Princenton University, 2010, pp. 15-29.

: "Les cinq sens au Moyen Âge. Etat de la question et perspectives de recherche", Cahiers de civilisation médiévale, 55, 2012, pp. 339-366.

: "Voir et entendre les chants de la messe", Codex Aquilarensis, 28, 2012, pp. 219-230.

: L' invention chrétienne des cinq sens dans la liturgie et l'art au Mogen Âge. París, Les Éditions du Cerf, 2014.

PANOFSKY, E.: Renacimiento y renacimientos en el arte occidental. Madrid, Alianza, 1975.

PARISSE, M.: "L'abbaye de Gorze dans le contexte politique et religieux lorrain á l'époque de Jean de Vandiéres (900-974)", dans: L'abbaye de Gorze au X siécle. Nancy, Collection Lorraine, 1993, pp. 51-90.

PEDREGAL, A.: "La Historia de las Mujeres y el Cristianismo primitivo. Apuntes para un balance historiográfico", en: La Historia de las Mujeres: Una revisión historiográfica. Secretaría de Publicaciones e Intercambio Editorial de la Universidad de Valladolid, 2004, pp. 201 228.

PÉREZ CARRASCO, F. J.: "La iglesia contra la carne. El programa contra la lujuria esculpido en la iglesia de Cervatos", Historia 16, no XVI, 1992, pp. 55-65.

: "Iconografía obscena en la escultura románica burgalesa", en: III Jornadas burgalesas de Historia Medieval. Burgos en la Plena Edad Media. Burgos, 1994, pp. 731-741. 
: “Lujuria, redención y concienca individual en un programa iconográfico en torno a 1200. La iglesia de Revilla de Santullán (Palencia)", Actas del IX Congreso Español de Historia del Arte. León, 1992, pp. 72-90.

PILOSU, M.: La Donna, la Lussuria e la Chiesa nel Medioevo. Génova, Edizioni Culturali Internazionali, 1989.

POILPRÉ, A-O.: "La Visibilité de Dieu dans les bibles carolinguiennes", dans: Les manuscrits carolingiens. Actes du Colloque de París, 2007, Turnhout, Brepols, 2009, pp. 185-2002.

POZA YAGÜE, M.: "La lujuria”, Revista Digital de Iconografía Medieval, vol. II, no 3, 2010, pp. 33-40.

: "Las portadas de los prioratos cluniacenses de Tierra de Campos en tiempos de Alfonso VI: una iconografía de corte monástico para una manifestación pública", Anales de Historia del Arte, 2 (volumen extraordinario), 2011, pp. 251-279.

PUENTE, G.: Ideología e Historia: El fenómeno estoico en la sociedad antigua. Madrid, Siglo XXI, 1974.

REAU, L.: Iconografía del Arte Cristiano. Iconografía de la Biblia. Tom.I / Vol. I. Barcelona, Ed. del Serbal, 1995.

REILLY, D. J.: "The Art of Reform in Eleventh-Century Flanders: Gerard de Cambrai, Richard de Saint-Vanne and the Saint-Vaast Bible", Studies in the History of Christian Traditions, Vol. 128, Leiden: Brill, 2006.

ROBERT, J. N.: Eros romano: Sexo y moral en la antigua Roma. Madrid, Editorial Complutense, 1999.
RODRÍGUEZ BARRAL, P.: "Reflexiones sobre el castigo de la avaricia y la lujuria a propósito de su representación en la escultura románica catalano-aragonesa", Codex Aquilarensis, no 21, 2005, pp. 6-28.

RODRÍGUEZ LÓPEZ, Mạ. I.: “Pervivencias iconográficas del mundo clásico en los códices prerrománicos: la personificación del mar", Cuadernos de Arte e Iconografía, no 11, 1993, pp. 218-224.

RODRÍGUEZ PÉREZ, D.: “El combate contra la serpiente: el triunfo de la tierra velado bajo la aparente muerte del oficio", De Arte, № 5, 2006, pp. 5-14.

: Serpientes, dioses y héroes: el combate contra el monstruo en el arte y la literatura griega antigua. Universidad de León, 2008.

: "La serpiente como símbolo en el mundo griego: Escenas del más acá", en Sabiduría simbólica y enigmática en la literatura grecolatina. Coord. Mạ Asunción Sánchez Manzano, 2011, pp. 97116.

: "La serpiente en la iconografía vascular griega del S.VI a.C.", en Ianua Classicorum: temas y formas del mundo clásico (2 Vols.), 2015, pp. 723-730.

ROSE, I.: Construire une société seigneuriale: itinéraire et ecclésiologie de I 'abbe Odon de Cluny (fin du IXe-milieu du Xe siécle). Brepols, Turnhout, 2008.

ROUSSELLE, A.: Porneia. De la maîtrise du corps á la privation sensorielle. Ile-IVe siécle de l'ére chrétienne. París, 1983.

RUIZ MONTEJO, I.: "La temática obscena en la iconografía del románico rural", Goya, no 147, 1978, pp. 136-146. 
SAN BENITO.: Su vida y su regla. Madrid, B.A.C., 1968.

SAN GREGORIO MAGNO.: Libro II de los Diálogos. Vida y milagros del Venerable Benitor fundador y abad del Monasterio de "Arcis" de la provincia de Campania. Madrid, B.A.C., 1968. Commento morale a Giobbe. Roma, Bibliotheca Gregorii Magni; Cittá Nuova Editrice, 2001.

SAN ISIDORO DE SEVILLA.: Etimologías. Ed. J. Oroz Reta; M. A. Marcos Casquero. Madrid, B.A.C., 1983.

SAUGNIEUX, J.: "Culture religieuse et culture profane. Les representations de la luxure dans l'art francais du XIle siécle", dans: Cultures populaires et cultures savantes en Espagne du Moyen Age aux Lumiéres. París, CNRS, 1982, pp. 80-91.

SCHMITT, J. C.: "Cuerpo y alma", En: Diccionario razonado del Occidente Medieval. J .Le Goff; J. C.Schmitt eds. Madrid, Akal, 2003, pp. 189198.

: Les Corps, les rites, les réves, le temps. Essais d'antrophologie médiévale. París, Gallimard, 2001.

SEGRE, C.: Fuori del mondo. I modelli nella follia e nelle immagini dell 'aldila. Turín, 1990.

SERRATO, M.: Ascetismo femenino en Roma. Estudios sobre San Jerónimo y San Agustín. Universidad de Cádiz, 1993.

SETTIS, S.: “Continuitá, distanza, conoscenza. Tre usi dell'antico", en Memoria dell'antico nell'arte italiana, III, Turín, 1986.
SEZNEC, J.: Los dioses de la Antigüedad en la Edad Media y el Renacimiento. Madrid, Taurus, 1983.

SOLIGNAC, A.: "Péchés capitaux", dans: Dicctionaire de spiritualité ascétique et mistique. Tomo XII, 1. París, 1984, pp. 853-862.

SPECIALE, L.: Montecassino e la Riforma Gregoriana. L'Exultet Vat. Barb. Lat. 592. Roma, 1991.

TERTULIANO.: De Cultu Feminarum o El adorno de las mujeres. Málaga, Servicio de Publicaciones de la Universidad de Málaga, 2001.

TOLDRÁ I VILARDELL, A.: Asmodeu. Dona, dimoni y sexe a l'edat mitjana. Universitat de Valencia, 2011.

TOUBERT, H.: Un art dirigé: réforme grégorienne et iconographie. París, Editions du Cerf, 1990.

Trésors carolingiens. Livres manuscrits de Charlemagne á Charles le Chauve. Bibliotheque Nationale de France, 2007.

TRIVELLONE, A.: L'hérétique imaginé: hétérodoxie et iconographie dans I 'Occident médiéval. Brepols, Turnhout, 2009.

_: "L'arte e la Riforma ecclesiastica tra XI e XII secolo", dans Medioevo, Cattedrali, Cavalieri, Cittá, sous la direction d'Umberto Eco. Milán, Encycomedia, 2011, pp. 605-611.

TURCAN-VERKERK, A. M.: "Le Scriptorium de Saint-Vanne de Verdun sous I 'abbatiat de Richard (1004-1046)", Scriptorium, 46, 1992, pp. 204223. 
VANDERPUTTEN, S.: "Identité collective et mémoire des réformes "richardiennes" dans I'historiographie bénedictine en BasseLotharingie et au Nord-Est de la France (Xle-XIle siécles)", Le Moyen Âge 2/2011, tome CXVII, pp. 259-289.

: Imagining Religious Leadership in the Middle Ages. Richard of SaintVanne and the Politics of Reform. Cornell University Press, 2015.

VAUCHEZ, A.: La espiritualidad del Occidente medieval. Madrid, Cátedra, 1985.

: Les laïcs au Moyen Âge. Practiques et experiences religieuses. París, Les editions du Cerf, 1987.

VECCHIO, S.: "Passions de l'âme et péchés capitaux: les ambigüites de la culture médiévale", in: Laster im Mittelalter/ Vices in the Middle Ages. Berlín-New York, Ed. by C. Flüeler and M. Rohde, 2009.

VERDON, J.: El Amor en la Edad Media. La carne, el sexo y el sentimiento. Barcelona, Paidós, 2008.

VEYNE, P.: La famille et l'amour sous le haut Empire romain. Annales E.S.C., 1978.

: La Société romaine. París, Seuil, 1991.

VV. AA.: Obras completas de San Jerónimo. Madrid, B.A.C., 1999.

VV. AA.: Exultet, Rotoli liturgici del medioevo meridionale. Roma, 1994.

VV.AA.: Religion et Culture autor de I'an Mil. Royaume capétien et Lotharingie. París, Picard, 1990.

VV. AA.: "Sueños, ensueños y visiones en la Antigüedad pagana y cristiana" (Coord. R. Teja). Codex Aquilarensis, № 18, 2002.
WAGNER, A.: "Richard de Saint-Vanne (1004-1046) est l'esprit de sa reforme", dans: L'ecrit et le livre peint en Lorraine, de Saint-Mihiel á Verdun (IXe-XVe siécles). Actes du Colloque de Saint-Mihiel (25-26 octobre 2010), Brepols Publishers, 2014, pp. 105-120.

WEIR, A.; JERMAN, J.: Images of Lust. Sexual carvings on medieval churches. London, B.T. Batsford Ltd., 1986.

WEISBACH, W.: Reforma religiosa y arte medieval. La influencia de Cluny en el Románico occidental. Madrid, Espasa-Calpe, 1949

WELTER, J. Th.: L'Exemplum dans la littérature religieuse et didactique du Moyen Âge. París-Toulouse, Bibliotheque d'histoire ecclésiastique de France, 1927.

WENIN, A.: "La serpiente y la mujer o el proceso del Mal según Génesis 23", Concilium, Revista Internacional de Teología, 304, 2004, pp. 4755.

WILLIAMSON, P.: Medieval Ivory Carvings. Early Christian to Romanesque. London, V\&A Publishing, Victoria and Albert Museum, 2010.

WIRTH, K. A.: "Erde", Reallexicon zur deutschen Kunstgeschichte. Tom. V. pp. 997-1103.

YARZA LUACES, J.: "Iconografía de la Crucifixión en la miniatura española. Siglos X al XII", Archivo Español de Arte 47, 185, 1974, pp. 20-30.

: "De casadas estad sujetas a vuestros maridos, como conviene en el Señor" a "Señora soy vuestro vasallo, por juramento y compromiso", Actas de las III Jornadas de Investigación Interdisciplinar sobre la Mujer: La imagen de la Mujer en el Arte Español. Madrid, 1984, pp. 53-71. 